Article

\title{
Thermal Performance of a Massive Wall in the Mediterranean Climate: Experimental and Analytical Research
}

\author{
Chiara Tribuiani * ${ }^{\mathbb{D}}$, Luca Tarabelli $\mathbb{D}^{\text {, }}$, Serena Summa ${ }^{\mathbb{D}}$ and Costanzo Di Perna * \\ Department of Industrial Engineering and Mathematical Sciences, Università Politecnica delle Marche, \\ via Brecce Bianche 1, 60131 Ancona, Italy; 1.tarabelli@univpm.it (L.T.); s.summa@pm.univpm.it (S.S.) \\ * Correspondence: c.tribuiani@pm.univpm.it (C.T.); c.diperna@univpm.it (C.D.P.)
}

Received: 14 June 2020; Accepted: 1 July 2020; Published: 3 July 2020

\begin{abstract}
In the Mediterranean climate, indoor overheating and, thus, excessive use of cooling systems represents one of the main problems both for the occupants' health and energy consumption. In order to limit this problem, an appropriate design or energy retrofitting of the building envelope is of utmost importance. The predominance of massive buildings in the Italian territory and the need to comply with Italian regulations often leads technicians to not optimal energy saving solutions. To this purpose, this experimental research was conducted on a mockup building, located in Fabriano and characterized by high thermal mass walls (W0) and two different external insulating systems: Cork based lightweight plaster (W1) and Extruded polystyrene foam panel (XPS) (W2). Furthermore, a virtual model in TRNSYS, a transient simulation software, was used to compare analytical and simulated values. Results show that W2 undergoes a higher level of thermal stress than $\mathrm{W1}$, due to higher peaks in the external surface temperature and larger fluctuations in daily temperature. Therefore, a high value of thermal resistance of the external insulation and low value of external areal heat capacity on a massive building causes external surface overheating problems, thus, not representing the optimal construction solution.
\end{abstract}

Keywords: thermal inertia; insulated external wall; thermal resistance; external areal heat capacity; building envelope; experimental study

\section{Introduction}

The buildings sector, which includes residential and commercial structures, increases its energy consumption by $1.3 \%$ per year. The predicted amount of delivered energy for the buildings sector will show an increase in consumption of about $20 \%$ in 2018 and $22 \%$ in 2050 [1].

The European regulation, in particular, EPB Directive 2018/844, aims to promote a greater diffusion of energy efficiency and renewable energy in buildings, in order to achieve reductions in greenhouse gas emissions and help increase the security of energy supply at the same time [2].

Many studies proved that the building energy consumption is mainly influenced by six factors, as defined by the International Energy Agency (IEA): (1) Climate, (2) building envelope, (3) building services and energy systems, (4) building operation and maintenance, (5) occupant activities and behavior, and (6) indoor environmental quality provided. In order to identify opportunities on energy saving, building energy data, concerning the six factors, were studied [3].

European work groups forecasted a further increase in cooling energy consumption rather than in heating energy consumption. In the construction sector, one of the main reasons is represented by the urban heating island (UHI), which leads to overheating of the cities and, thus, to a growing increase in cooling energy demand [4]. 
Indoor overheating in summer represents a problem for both occupants' health and energy consumption, due to the overuse of cooling systems. Highly insulated buildings with no good ventilation are affected by this problem; therefore, in order to find the best solutions in terms of indoor comfort and saving cost for the hot climate, Congedo et al. studied different combinations of walls, windows, and technical systems with high masses [5].

Similar studies were carried out for buildings located in a hot tropical climate, which generally suffer overheating all year long, due to their warm weather conditions. Gamero-Salinas et al. showed how the overheating risk can be lowered in massive wall buildings if coupled with adequate passive ventilation, especially during nighttime, when walls re-radiate stored heat [6-8].

Recent experimental studies highlighted how the monitored indoor air temperature in lightweight buildings tends significantly to rise faster than in heavyweight buildings, in which thermal capacity allows attenuating the daily indoor air temperature fluctuations. The problem of increasing in building energy consumption should be faced through passive cooling techniques, which include solar and heat protection, i.e., high thermal inertia, thermal insulation, shading devices, paintings with low colour absorption, night ventilation, and evaporative cooling. Van Hoff et al. proved that the combined use of three passive strategies such as solar shadings, natural ventilation, and heavyweight construction can lower the cooling energy demand from $74 \%$ to $59 \%[9,10]$.

Kuczynski et al. demonstrated how thermal inertia of the building provides benefit to both thermal comfort and decrease in cooling energy demand in temperate climates during summer. Indeed, from some of these studies, buildings with a high thermal mass reduced the cooling energy demand by $67-75 \%$ depending on the assumed temperature threshold. Furthermore, buildings with a high thermal inertia show larger attenuation of daily indoor air temperature fluctuations [11,12].

Baglivo et al. reported many studies about building envelope performances, which proposed high efficiency solutions suitable for warm and cold climates. In composite climates, a wall with high thermal mass guarantees comfort in both summer and winter; in cold climates, a thick multi-layer wall consisting of a low-density insulating layer, which allows reaching lower thermal transmittance values, is preferred. Whereas in warm climates, an external wall with low decrement factor, high internal areal capacity, and suitable time-shift is preferred. Moreover, in order to avoid summer overheating, windows and shading systems are of utmost importance. Study results demonstrate that a double layer of tuff with a massive layer in the internal side and a resistive layer outside is the most suitable solution in the Mediterranean climate to maintain a comfortable operative temperature [13-15].

$\mathrm{Xu}$ et al. analyzed the position of insulating layer, focusing on relative humidity and the way it influences heat transfer mechanisms. Their results show that insulation on the internal side of the wall is the worst under an internal relative humidity condition of $70 \%$; therefore, insulation on the external side of the wall is the most suitable solution in the climate characterized by a hot summer and cold winter [16]. Cheng et al. showed that the thermal insulation layer on the outside represents the best solution to reduce heating and cooling energy demand [17].

The interest for the issue of thermal inertia in buildings is still remarkable; Verbekea et al. [18] highlighted the impacts of building thermal inertia on thermal comfort and on heating or cooling energy demand. The capacity of attenuating heat fluctuations and time shifting are related to the thermal inertia of the building. It is widely recognized that a suitable solution in building design for most climates and intended uses is represented by a wall with high thermal mass located at the inner side of the thermal insulation. However, thermal inertia is a complex phenomenon and should be evaluated considering several factors, i.e., building location, intended use, and the thermal insulation of the building envelope.

The majority of the buildings of urban fabric in old Italian towns has a huge thermal mass wall, which do not respect the current normative limits imposed for the thermal resistance $(\mathrm{R})$ and, therefore, for the thermal transmittance (U). In order to improve thermal efficiency and guarantee living indoor comfort, identifying the best insulation techniques valid for both winter and summer periods is of utmost importance. 
Several authors, including Stazi et al., conducted studies aimed at identifying the best energy-efficient retrofitting methods; thus, analyzing how the position of insulating layer influences the behavior of building characterized by high thermal mass walls, especially, in a Mediterranean climate. Results show how passive strategies, such as natural ventilation, can lower the overheating of an internal environment in hyper-insulated buildings. Furthermore, the experimental study on several building retrofitting methods highlight that the best solution is represented by a massive external and well-insulated wall coupled with ventilated cavities [19].

Rossi et al. proved the importance of high thermal inertia in the building envelope, focusing on the problem of reduction of the cooling energy demand. This study also demonstrates that defining reference values for superficial mass $\left(\mathrm{M}_{\mathrm{s}}\right)$ and periodic thermal transmittance $\left(\mathrm{Y}_{\mathrm{mn}}\right)$ is not exhaustive to investigate the effects of thermal inertia on the summer performances of walls in Southern Europe. For this reason, other parameters are studied in a high thermal capacity wall, i.e., internal areal heat capacity $\left(\mathrm{k}_{1}\right)$ and decrement factor $(\mathrm{f})$. Moreover, in order to determine energy consumption, weather conditions are of utmost importance: Given the same $Y_{m n}$ and $k_{1}$ values, the research shows different energy consumptions in several Italian geographic areas (Milan and Catania). Furthermore, the mass of external wall represents another fundamental parameter because the best results were found in heavyweight walls [20-22].

Moreover, Stazi et al. highlighted the limits of the use of a lightweight building and hyper-insulated wall, focusing their analysis on the study of two coupled factors, namely the internal areal heat capacity $\left(\mathrm{k}_{1}\right)$ and decrement factor $(\mathrm{f})$. Their results show that the optimal combination in a hot summer climate is represented by high internal areal heat capacity equal to $30 \mathrm{~kJ} / \mathrm{m}^{2} \mathrm{~K}$ and decrement factor bigger than $0.07[23]$.

Based on the studies mentioned above, this research wants to analyze possible correlations between thermal resistance $(R)$ and external areal heat capacity $\left(k_{2}\right)$ of massive buildings with different external thermal insulation layers. Thus, this paper presents an experimental research conducted on a mockup building characterized by both high thermal mass and high insulation. The experimental building is located in Fabriano, whose zone is classified in Group C (temperate climate), specifically Cfa (humid subtropical climate), in accordance with the Köppen-Geiger climate classification system. Table 1 presents summer average weather data obtained through interpolation of values from the three nearest weather stations (Perugia, Frontone, Ancona/Falconara), officially recognized by the World Meteorological Organization (WMO).

Table 1. Summer average interpolated weather data.

\begin{tabular}{cccccc}
\hline Month & $\begin{array}{c}\text { Outdoor Air } \\
\text { Temperature } \\
\left({ }^{\circ} \mathbf{C}\right)\end{array}$ & $\begin{array}{c}\text { Relative } \\
\text { Humidity } \\
\mathbf{( R H} \%)\end{array}$ & $\begin{array}{c}\text { Wind Speed } \\
\mathbf{( m / s )}\end{array}$ & $\begin{array}{c}\text { Solar Global Irradiance } \\
\text { on Horizontal Plane } \\
\mathbf{( W m}^{-2} \mathbf{)}\end{array}$ & $\begin{array}{c}\text { Atmospheric } \\
\text { Pressure (hPa) }\end{array}$ \\
\hline June & 22.9 & 51 & 2.8 & 255 & 977 \\
July & 25.4 & 44 & 3 & 281 & 978 \\
August & 24.9 & 50 & 2.8 & 234 & 978 \\
\hline
\end{tabular}

The main contributions of the paper are:

- Bringing new experimental data on the study of the building envelope behavior under summer Mediterranean climate conditions.

- Gaining knowledge about the building envelopes with different external insulating materials.

In order to identify an appropriate construction solution for the Mediterranean climate, and to limit external surface overheating on a massive building, due to particular insulating layers, this study compares the thermal performances of a massive wall, characterized by two different insulating systems, under the same Mediterranean weather conditions.

The rest of the paper is structured as follows: In Section 2, we present the materials and methods used for the experimental campaign, while in Section 3, we show the results obtained with the 
on-site monitoring and through a virtual model in Transient System Simulation Program TRNSYS, (Solar Energy Laboratory, University of Wisconsin, Madison, WI, USA).

Finally, in Section 4, we draw some conclusions about the results shown and we discuss future work.

\section{Materials and Methods}

This paper presents an experimental study of a high thermal mass building, which was thermally insulated with two different materials to reach the thermal transmittance limit provided by the Italian national regulation.

In order to investigate the behavior of different external insulating walls in a temperate climate, the measurement campaigns were carried out in summer 2018 and 2019.

The monitored mockup is an experimental building made in lightweight concrete (LWC) with lightweight recycled glass aggregates: This concrete mix design allows reaching a mechanical resistance class of LC 8/9. LWC is an innovative material with good resistance properties and thermal characteristics, i.e., thermal conductivity $\lambda$ of $0.27 \mathrm{~W} \mathrm{~m}^{-1} \mathrm{~K}^{-1}$, specific heat capacity $c$ of $1000 \mathrm{~J} \mathrm{~kg}^{-1} \mathrm{~K}^{-1}$, and density $\rho$ of $1200 \mathrm{~kg} \mathrm{~m}^{-3}$. Thus, LWC represents an optimal solution to construct a monolithic building, as the one analyzed in this research, which is characterized by a high thickness $t$ of $70 \mathrm{~cm}$.

The aim of this study is to compare the behavior of the building envelope with different external insulating layers. Therefore, the study focused on the performance of the Southeast-oriented façade, the most exposed to daylight, which were insulated with two different external insulating linings. Specifically, the initial wall composed of a single layer of LWC, named "as build" state (Wall 0, material Type 0), was divided in half: In the first half, a cork based lightweight plaster (Wall 1, material Type 1) was applied, in the second half, an XPS panel (Wall 2, material Type 2).

The cork based lightweight plaster (Type 1) is characterized by a thickness $t$ of $4 \mathrm{~cm}$, a thermal conductivity $\lambda$ of $0.037 \mathrm{~W} \mathrm{~m}^{-1} \mathrm{~K}^{-1}$, a specific heat capacity $c$ of $1100 \mathrm{~J} \mathrm{~kg}^{-1} \mathrm{~K}^{-1}$, and a density $\rho$ of $280 \mathrm{~kg} \mathrm{~m}^{-3}$. An extruded polystyrene insulation, XPS board (Type 2), is featured by a thickness $t$ of $8 \mathrm{~cm}$, a thermal conductivity $\lambda$ of $0.036 \mathrm{~W} \mathrm{~m}^{-1} \mathrm{~K}^{-1}$, a specific heat capacity $c$ of $1450 \mathrm{~J} \mathrm{~kg}^{-1} \mathrm{~K}^{-1}$, a density $\rho$ of $35 \mathrm{~kg} \mathrm{~m}^{-3}$.

In order to protect the external insulating layers, a smooth finishing plaster (Type 3) is applied, which is composed of natural lime binders, mineral expanded fillers, and pure limestone powder, grain size $0-0.6 \mathrm{~mm}$. The lightweight smooth finishing plaster is characterized by a thickness $t$ of $5 \mathrm{~mm}$, a thermal conductivity $\lambda$ of $0.128 \mathrm{~W} \mathrm{~m}^{-1} \mathrm{~K}^{-1}$, a specific heat capacity $c$ of $1000 \mathrm{~J} \mathrm{~kg}^{-1} \mathrm{~K}^{-1}$, and a density $\rho$ of $1165 \mathrm{~kg} \mathrm{~m}^{-3}$. The external smooth finishing plaster has the same color and surface roughness for both analyzed surfaces.

The two thermal insulation materials, Type 1 and Type 2, were chosen for similar thermal conductivity $\lambda$, but different specific weight $\rho$ and water vapor permeability $\mu$. The thermal lightweight plaster, composed of natural hydraulic lime, has a higher porosity and breathability than the XPS panel, which is extruded polystyrene with a closed cell, characterized by good moisture resistance but less water vapor permeability.

The thermo-physical properties of the selected materials are presented in Table 2.

Table 2. Thermal characteristics of the insulating materials.

\begin{tabular}{cccccc}
\hline & & Type 0 & Type 1 & Type 2 & Type 3 \\
\hline Thickness $t$ & $(\mathrm{~cm})$ & 70 & 4 & 8 & 0.5 \\
Thermal conductivity $\lambda$ & $\left(\mathrm{W} \mathrm{m}^{-1} \mathrm{~K}^{-1}\right)$ & 0.27 & 0.037 & 0.036 & 0.128 \\
Specific heat $c$ & $\left(\mathrm{~J} \mathrm{~kg}^{-1} \mathrm{~K}^{-1}\right)$ & 1000 & 1100 & 1450 & 1000 \\
Density $\rho$ & $\left(\mathrm{kg} \mathrm{m}^{-3}\right)$ & 1200 & 280 & 35 & 1165 \\
Thermal diffusivity $a$ & $\left(\mathrm{~m}^{2} \mathrm{Ms}^{-1}\right)$ & 0.225 & 0.120 & 0.709 & 0.111 \\
Water vapor permeability $\mu$ & - & 22.6 & 3 & 150 & 15 \\
Surface absorption coefficient $\alpha$ & - & 0.6 & - & - & 0.3 \\
\hline
\end{tabular}


The Italian national regulation (DM 26/06/2015 [24]) provides a thermal transmittance U limit for retrofitting: In this case study, the limit is $0.28 \mathrm{Wm}^{-2} \mathrm{~K}^{-1}$ from 1 January, 2021, given the thermal zone (E) where the mockup is located.

The aim of this study is to compare the behavior of the building envelope with different external insulating layers. To this purpose, three wall types were defined with the following features:

- Wall 0: Wall constructed from LWC (Type 0);

- Wall 1: Wall 0 plus insulation made of a cork based lightweight plaster (Type 1) and finishing smoother (Type 3) to protect the external insulating linings;

- Wall 2: Wall 0 plus insulation made of an XPS panel (Type 2) and finishing smoother (Type 3) to protect the external insulating linings.

Wall 0 offers a thermal transmittance $\mathrm{U}$ equal to $0.36 \mathrm{Wm}^{-2} \mathrm{~K}^{-1}$, which is not sufficient to respect the Italian regulation. Therefore, in order to fulfil the national limit, two different types of insulating materials were chosen, thus, a transmittance value of 0.26 and $0.20 \mathrm{Wm}^{-2} \mathrm{~K}^{-1}$ were reached for Wall 1 and Wall 2, respectively.

The thermo-physical properties of the layer walls are presented in Table 3.

Table 3. Thermal characteristics of external walls.

\begin{tabular}{|c|c|c|c|c|}
\hline & & Wall 0 & Wall 1 & Wall 2 \\
\hline Total thickness $\mathrm{t}$ & $(\mathrm{cm})$ & 70 & 74.5 & 78.5 \\
\hline Position of insulating material & & diffuse & external & external \\
\hline Insulating thickness $t_{i}$ & $(\mathrm{~cm})$ & - & 4 & 8 \\
\hline \multicolumn{5}{|c|}{ Characteristics of the entire wall } \\
\hline Thermal resistance $\mathrm{R}$ & $\left(\mathrm{m}^{2} \mathrm{~K} \mathrm{~W}^{-1}\right)$ & 2.76 & 3.88 & 5.02 \\
\hline Thermal transmittance $U$ & $\left(\mathrm{~W} \mathrm{~m} \mathrm{~m}^{-2} \mathrm{~K}^{-1}\right)$ & 0.36 & 0.26 & 0.20 \\
\hline External areal heat capacity $\mathrm{K}_{2}$ & $\left(\mathrm{~kJ} \mathrm{~m}{ }^{-2} \mathrm{~K}^{-1}\right)$ & 58.3 & 15.6 & 9.3 \\
\hline Areal heat capacity K & $\left(\mathrm{kJ} \mathrm{m}^{-2} \mathrm{~K}^{-1}\right)$ & 840 & 862 & 853 \\
\hline \multicolumn{5}{|c|}{ Characteristics of single insulating layer } \\
\hline Thermal resistance Ri & $\left(\mathrm{m}^{2} \mathrm{KW}^{-1}\right)$ & 2.59 & 1.08 & 2.22 \\
\hline Areal heat capacity Ki & $\left(\mathrm{kJ} \mathrm{m}^{-2} \mathrm{~K}^{-1}\right)$ & 840 & 12.32 & 4.06 \\
\hline
\end{tabular}

The experimental mockup is located in Fabriano, in central Italy (latitude $43.329^{\circ}$, longitude $12.939^{\circ}$, altitude of $325 \mathrm{~m}$, and $2198^{\circ}$ days). Fabriano is characterized by a warm and temperate climate, classified as Cfa according to the Köppen-Geiger classification. A rural area without any other building or vegetation nearby was chosen to eliminate any possible influence on the performance of the mockup.

Monitoring campaigns were carried out during summer 2018 (specifically 15 June-5 September) and between spring and summer 2019 (specifically 27 May-16 July).

The measurement campaigns were carried out on a cubic prototype building positioned at an angle of $44^{\circ}$ from the South and featured with $70 \mathrm{~cm}$ thick walls, which provide a high thermal capacity. Thus, the total volume was $27 \mathrm{~m}^{3}$ and the internal volume was only $4.1 \mathrm{~m}^{3}$.

The mockup is equipped with no heating or cooling system, therefore no internal temperature control is allowed. In order not to have solar radiation heat gain from transparent elements, no window is present; moreover, there is only one square opening $(60 \times 60 \mathrm{~cm})$ on the Northwest-exposed façade, which was closed during monitoring campaigns with a polystyrene panel to reduce thermal dissipations.

The research project was carried out with the following steps:

- Site preparation to verify the necessary tools to install the mockup;

- Plan of sensor network and control systems;

- Detailed on site monitoring to analyze the summer dynamic behavior of the experimental case study; 
- Data collection and analysis of results. The study was conducted to analyze surface temperatures, heat fluxes, external weather data (outdoor air temperature, outdoor relative humidity, and global solar radiation on a horizontal plane), indoor air temperature, and relative humidity;

- Dynamic simulations of the mockup through the TRNSYS software, in order to test its efficiency with high thermal mass and insulated walls.

The experimental campaign required a preliminary plan of technical equipment needed for monitoring. The mockup is located in an isolated area without connection to the electricity distribution network, therefore the power supply for monitoring stations were obtained through a photovoltaic panel coupled with a storage battery.

The components of the electrical system were:

- Photovoltaic panel;

- Storage battery;

- PWM solar charge controller;

- Step-up DC / DC converter with a 4-30V output.

The scope of the present study is to investigate the thermal behavior of two different insulated building envelopes through the analysis of experimental data collected, i.e., weather conditions, indoor hygrothermal conditions, and envelope performances (surface temperatures and heat fluxes). Measurements, sensor types, and their position are presented in Table 4.

Table 4. Sensor details.

\begin{tabular}{|c|c|c|c|c|}
\hline Measure & Sensor Type & Position & Accuracy & Range \\
\hline \multicolumn{5}{|c|}{ Weather conditions } \\
\hline Air temperature & Thermo hygrometer & Weather station & $\pm 0.5^{\circ} \mathrm{C}$ & -40 to $65^{\circ} \mathrm{C}$ \\
\hline Relative humidity & Thermo hygrometer & Weather station & $\pm 3 \%$ & $0 \%$ to $100 \%$ \\
\hline Wind speed & Anemometer & Weather station & $\pm 0.5 \mathrm{~ms}^{-1}$ & 1.5 to $79 \mathrm{~ms}^{-1}$ \\
\hline Solar radiation & Radiometer & Weather station & $<5 \%$ & 0 to $1800 \mathrm{~W} \mathrm{~m}^{-2}$ \\
\hline \multicolumn{5}{|c|}{ Indoor climatic conditions } \\
\hline Air temperature & $\begin{array}{l}\text { Thermo } \\
\text { hygrometer/Platinum } \\
\text { resistor }\end{array}$ & $\begin{array}{l}\text { Weather station/centre } \\
\text { of cube }\end{array}$ & $\begin{array}{l} \pm 0.5^{\circ} \mathrm{C} \\
\pm 0.05^{\circ} \mathrm{C}\end{array}$ & $\begin{array}{c}0 \text { to } 60^{\circ} \mathrm{C} \\
-200 \text { to } 850^{\circ} \mathrm{C}\end{array}$ \\
\hline $\begin{array}{r}\text { Relative humidity } \\
\text { Building enve }\end{array}$ & $\begin{array}{l}\text { Thermo hygrometer } \\
\text { oe performance }\end{array}$ & \multicolumn{3}{|c|}{ Building envelope performance } \\
\hline Heat flow & Heatflux & Internal wall surface & $\pm 3 \%$ & $\pm 2000 \mathrm{~W} \mathrm{~m}^{-2}$ \\
\hline Surface temperature & Flat Thermistor & $\begin{array}{l}\text { External, inside lining, } \\
\text { internal surface }\end{array}$ & $\pm 0.05^{\circ} \mathrm{C}$ & -200 to $850^{\circ} \mathrm{C}$ \\
\hline
\end{tabular}

The analysis required the following data recordings:

- Weather conditions (air temperature, relative humidity, solar radiation, speed wind, rainfall) using a weather station (Davis Vantage Pro 2);

- Indoor microclimate conditions (air temperature and relative humidity) using a second weather station. An additional probe, i.e., a platinum resistor (Pt100), was positioned in center of the room to check the indoor air temperature;

- Surface temperatures of different layers of the building envelope using flat thermistors (Pt100);

- Incoming and outgoing heat fluxes through the external building envelope using a heat fluxmeter.

Data were stored with a data logger (data Taker DT500), which collected output of the probes with a 5 min rate.

Summarizing, data recording required the following sensors (see Figures 1 and 2):

- 1 flat thermoresistances Pt100 on the external surface of Wall 1;

- 1 flat thermoresistances Pt100 on the external surface of Wall 2; 
- 3 flat thermoresistances Pt100 on the surface between material Type 1 and Wall 0;

- 1 flat thermoresistances Pt100 on the surface between material Type 2 and Wall 0;

- 1 flat thermoresistances Pt100 on the internal surface of Wall 1;

- 1 flat thermoresistances Pt100 on the internal surface of Wall 2;

- 1 heat fluxmeter on the internal side of the wall.

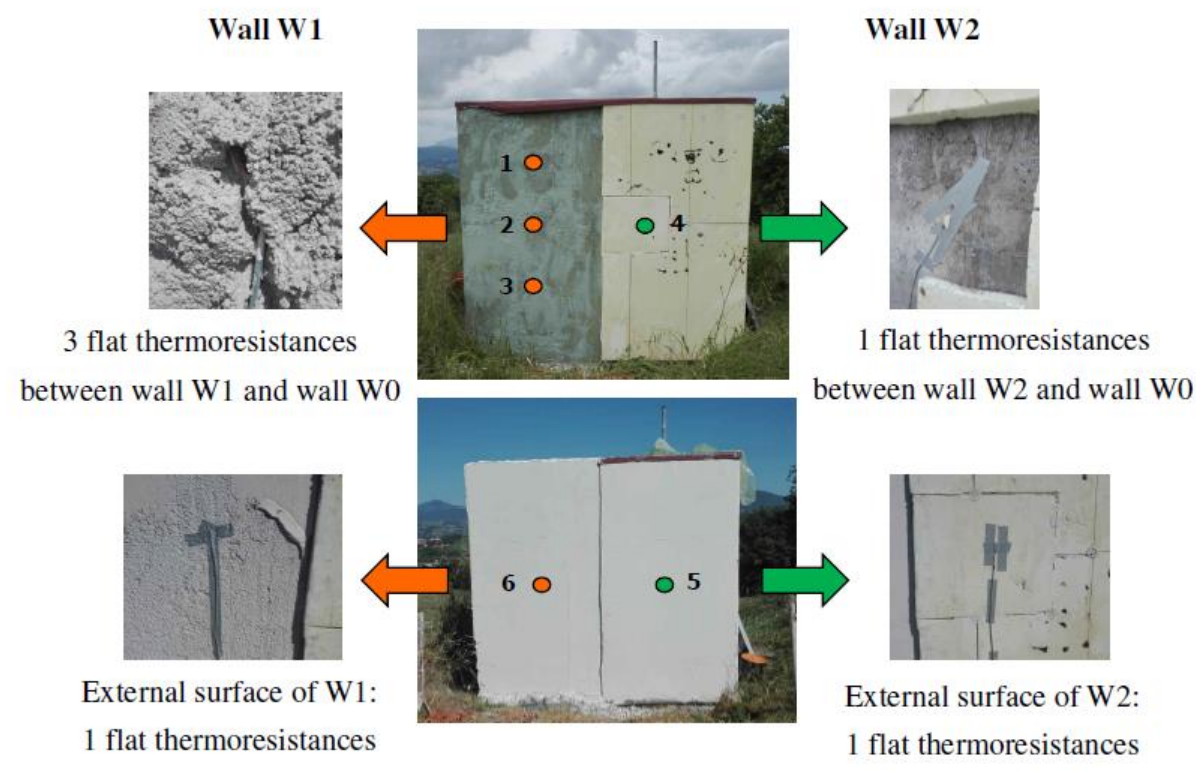

Figure 1. External view of the mockup on the Southeast façade: External probes installation phases on Wall 1 and Wall 2.

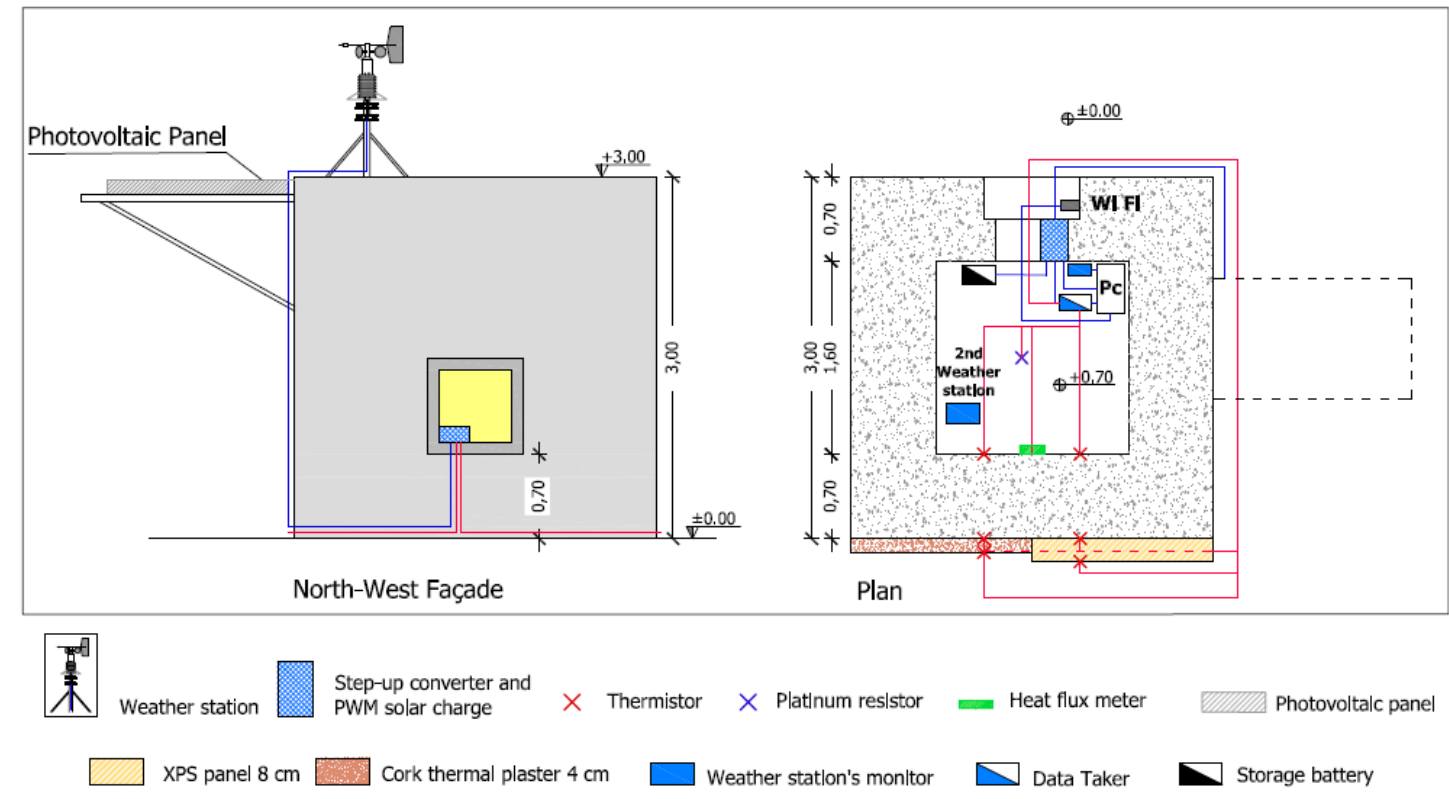

Figure 2. Experimental setup: Plan and Northwest façade, with sensor networks and control systems.

Even if the middle scale, the mockup is not representative of a real building, it is efficient for evaluating the influence of a massive and insulated wall on heat flux and surface temperatures during the summer time. In order to study the behavior of insulating materials on a high thermal capacity wall, the mockup was not equipped with a heating or cooling system to control the indoor temperature, thus it operates in free-floating conditions. 
In order to study the temperature distribution over the layers of the building envelope, the collected experimental measures refer to each layer composing the wall.

The analysis focused on the performances of the Southeast façade, which was divided into two surfaces: The first half was insulated with cork thermal plasters $4 \mathrm{~cm}$ (Wall 1) and the other half with an XPS panel $8 \mathrm{~cm}$ (Wall 2).

In order to analyze and compare different building envelope solutions, a plan was formulated to appropriately position thermal probes on each surface.

1. Wall 1. On external surface: Application of an acrylic primer to improve adhesion between the cement (Wall 0) and cork thermal plaster; position of the probes (one in the lower part of the surface, one in the center, and one in the upper part); application of $4 \mathrm{~cm}$ of thermal plaster; after the plaster drying time (about 14 days), position of another probe at half of its height; application of a finishing smoother. On the internal side position of a probe at half of the height of the surface.

2. Wall 2. On external surface: Position of a probe in the center of Wall 0. Mechanical installation of XPS panels; position of another probe at half of its height; application of finishing smoother. On the internal side position of a probe at half of the height of the surface.

In order to monitor thermal fluxes through the Southeast façade, a heat fluxmeter was fixed in the center of the internal surface.

All probes were placed to the same distance from the sides of the façade to avoid edge effects, which could compromise the measurements.

Moreover, several thermal analyses of the building were carried out simulating the physical phenomenon through a virtual model in TRNSYS, a transient simulation software that allows studying the thermal behavior of dynamics systems such as buildings. The cubic prototype building, featured with a high thermal capacity, was modeled in TRNBuild (Solar Energy Laboratory, University of Wisconsin, Madison, WI, USA), an interface for modeling geometry, walls, gains, ventilation, and infiltration profiles of a building having single or multiple thermal zones. Figure 3 displays the flowchart implemented in TRNSYS.

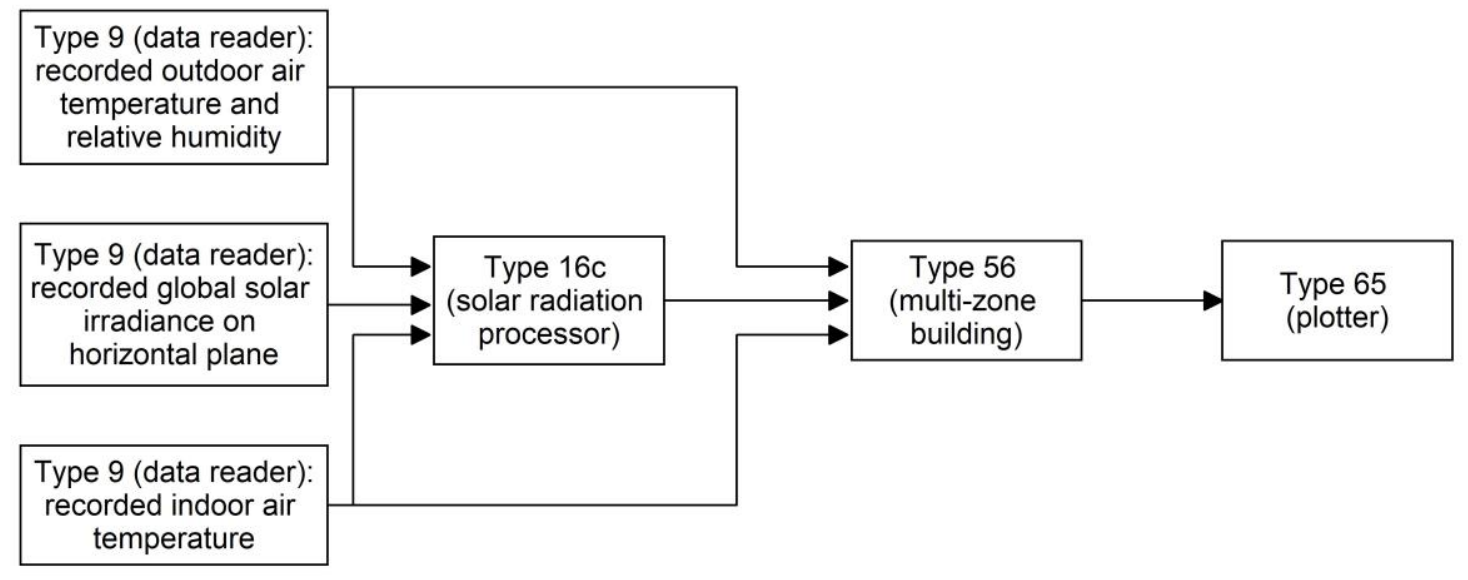

Figure 3. TRNSYS simulation model flowchart.

The outdoor and indoor environmental data collected were inputted through the TRNSYS component Type 9 to the simulation. Outdoor weather data (outdoor air temperature, outdoor relative humidity, and global solar radiation on a horizontal plane) were inputted in accordance with component Type 16c, a solar radiation processor which implements the Reindl [25] model to obtain beam and diffuse solar radiation as a function of global solar radiation on horizontal, ambient temperature, relative humidity, clearness index, and solar altitude angle; moreover, the Perez 1990 model [26] was chosen to calculate beam and diffuse solar irradiance on each tilted and oriented surface of the mockup. 
Component type 56 allowed creating the building by modeling its geometry and walls: Wall 0 , Wall 1, and Wall 2 were created and the thermo-physical properties of the materials composing their layers were defined, as reported in Tables 1 and 2. Moreover, a heating/cooling system with unlimited power was set to maintain indoor air temperature as the measured values, thus, the heating/cooling set-point temperatures were input through the TRNSYS component Type 9 to the simulation. No gains, ventilation, and infiltration profiles were added to the building model.

In order to compare simulated results with measured values, the following outputs were analyzed: Energy need, external and internal superficial temperatures of a wall, and energy from the inside surface including convection to the air and longwave radiation to other surfaces.

\section{Results}

This section reports results obtained with the seasonal monitoring campaigns in 2018 and 2019. Except for solar irradiance on the Southeast façade, which was calculated from the recorded solar global irradiance on a horizontal plane through the combination of Reindl and Perez's models, all the other presented results were experimentally recorded.

In order to compare and analyze the behavior of the insulating materials, wall W1 and wall W2 were tested under the same weather conditions. Similar trends are noticed in both 2018 and 2019, therefore, the following detailed analysis refers to the 2018 campaign only.

\subsection{Experimental Results Summer 2018}

The monitoring campaign was carried out between 15 June and 5 September 2018. The recorded average temperatures are $19.6{ }^{\circ} \mathrm{C}$ in June, $24^{\circ} \mathrm{C}$ in July, and $23.3^{\circ} \mathrm{C}$ in August.

Two periods of six consecutive days were chosen as representative of the summer results in 2018: 10-15 July and 2-7 August.

Concerning the representative days in July, the highest recorded outdoor air temperature is $31.9^{\circ} \mathrm{C}$ on 14 July at 2:00 p.m., the lowest is $13.6^{\circ} \mathrm{C}$ on 10 July at $6: 00 \mathrm{a} . \mathrm{m}$. The average air temperature over six days is $24.2^{\circ} \mathrm{C}$. The maximum daily temperature variation is $15.8^{\circ} \mathrm{C}$ on $10 \mathrm{July}$. The highest solar irradiance on the Southeast façade over the period is $509 \mathrm{Wm}^{-2}$ on $10 \mathrm{July}$.

Concerning the representative days in August, the average air temperature over six days is $25.4^{\circ} \mathrm{C}$; the maximum peak is $33.5^{\circ} \mathrm{C}$ on 7 August at 2:00 p.m., while the minimum peak is $17.3^{\circ} \mathrm{C}$ on 6 August at 5:00 a.m. The maximum daily temperature variation is $16.0^{\circ} \mathrm{C}$ on 6 August. The highest solar irradiance on the Southeast façade over the period is $475 \mathrm{Wm}^{-2}$ on 6 August.

Figures 4 and 5 show the comparison between outdoor air temperature and global solar irradiance on a Southeast oriented surface during the selected periods. Since the analyzed surface is Southeast oriented, solar irradiance has its maximum values around 10:00 a.m., while the maximum air temperature values are reached around 2:00 a.m. for both periods.

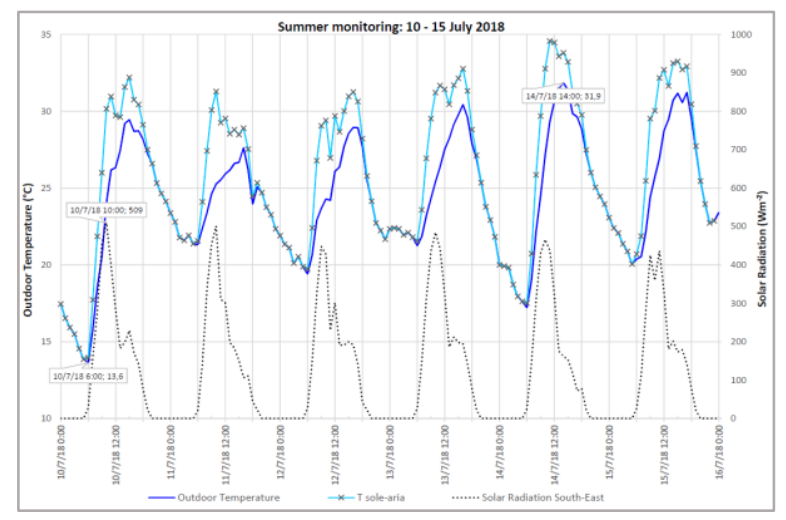

Figure 4. Outdoor air temperature, solar irradiance on Southeast, and sol-air temperature for 10-15 July. 


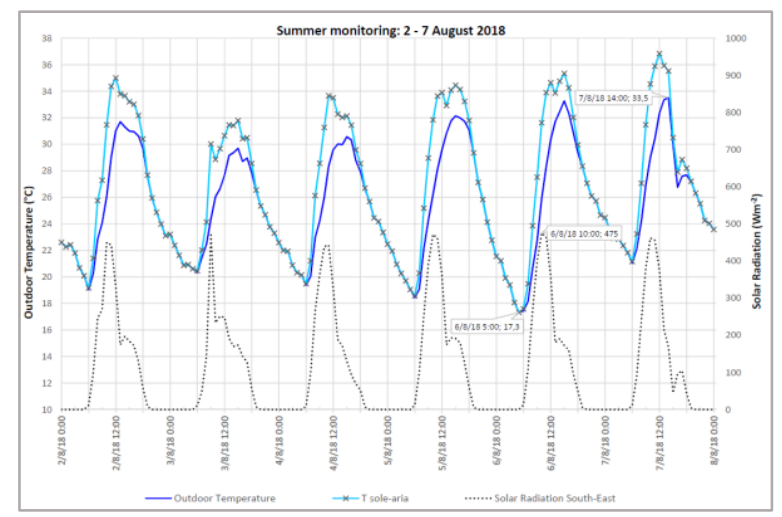

Figure 5. Outdoor air temperature, solar irradiance on Southeast, and sol-air temperature for 2-7 August.

The minimum air temperatures are recorded between 6:00 a.m. in July and 5:00 a.m. in August.

The sol-air temperature shows the correlation between outdoor air temperature and solar irradiance: Indeed, it represents an outdoor air temperature value, which includes incident solar radiation, radiant energy exchange with the sky and outdoor environment, and air-to-air temperature exchange [27]. The sol-air temperature is defined by a measured outdoor air temperature, solar irradiance on a tilted surface of fixed orientation of the mockup (South-East), surface absorptance coefficient for solar radiation (for light-colored surfaces, usually assumed $\alpha=0.3$ ), and external surface heat transfer coefficient $\left(25 \mathrm{Wm}^{-2} \mathrm{~K}^{-1}\right)$.

The following experimental data are the external and internal surface temperatures of walls W1 and W2 and the heat flux through the wall compared to solar irradiance on the Southeast façade, outdoor air temperature, and indoor air temperature of the mockup.

The simultaneous monitoring of two different insulating systems, i.e., Wall 1 and Wall 2, allows the various solutions to be compared in both the selected summer periods.

Figure 6 shows a comparison between external surface temperatures of W1 and W2 during the first analyzed period (10-15 July): The temperature of wall W1 is always lower than wall W2 during the daytime, while the opposite behavior is shown during the nighttime. Specifically, the highest values are recorded on $15 \mathrm{July}$, namely, $33.5^{\circ} \mathrm{C}$ for $\mathrm{W} 1$ and $35.5^{\circ} \mathrm{C}$ for $\mathrm{W} 2$, while the maximum difference between the daily maximum and minimum external surface temperatures is $15.8^{\circ} \mathrm{C}$ for $\mathrm{W} 1$ and $20.0^{\circ} \mathrm{C}$ for W2 on 10 July.

Therefore, the XPS insulating system, wall W2, is more thermally stressed than W1, due to higher peaks in external surface temperature and large fluctuations in daily temperature.

External surface temperatures during the second analyzed period (2-7 August) for the two different insulated walls are shown in Figure 7. The highest recorded values are $37.2^{\circ} \mathrm{C}$ for $\mathrm{W} 1$ and $39.3^{\circ} \mathrm{C}$ for W2 on 7 August, while the largest difference between the daily maximum and minimum external surface temperatures is $18.3^{\circ} \mathrm{C}$ for $\mathrm{W} 1$ and $22.3^{\circ} \mathrm{C}$ for $\mathrm{W} 2$ on 6 August.

Thus, W1 and W2 show a similar behavior in both the analyzed summer periods.

In order to deeply analyze the behavior of the two insulating systems (Wall 1 and Wall 2), Figures 8 and 9 show temperatures measured between Wall 0 and W1 or Wall 0 and W2 and those on the internal surface on 10-15 July.

Contrary to external surface temperatures, those measured between Wall 0 and insulating layer $\mathrm{W} 2$, are more reduced than those between Wall 0 and W1, e.g., W1 range between 17.3 and $28.0^{\circ} \mathrm{C}$, over the whole period while the wall W2 ranges between 22.1 and $25.1^{\circ} \mathrm{C}$.

Furthermore, an almost linear trend for the indoor air temperature and internal surface temperature is noticed for both the insulating systems; specifically, W2 shows similar values to indoor air temperature; indeed, the two curves overlap, while W1 temperatures are always lower than W1. 


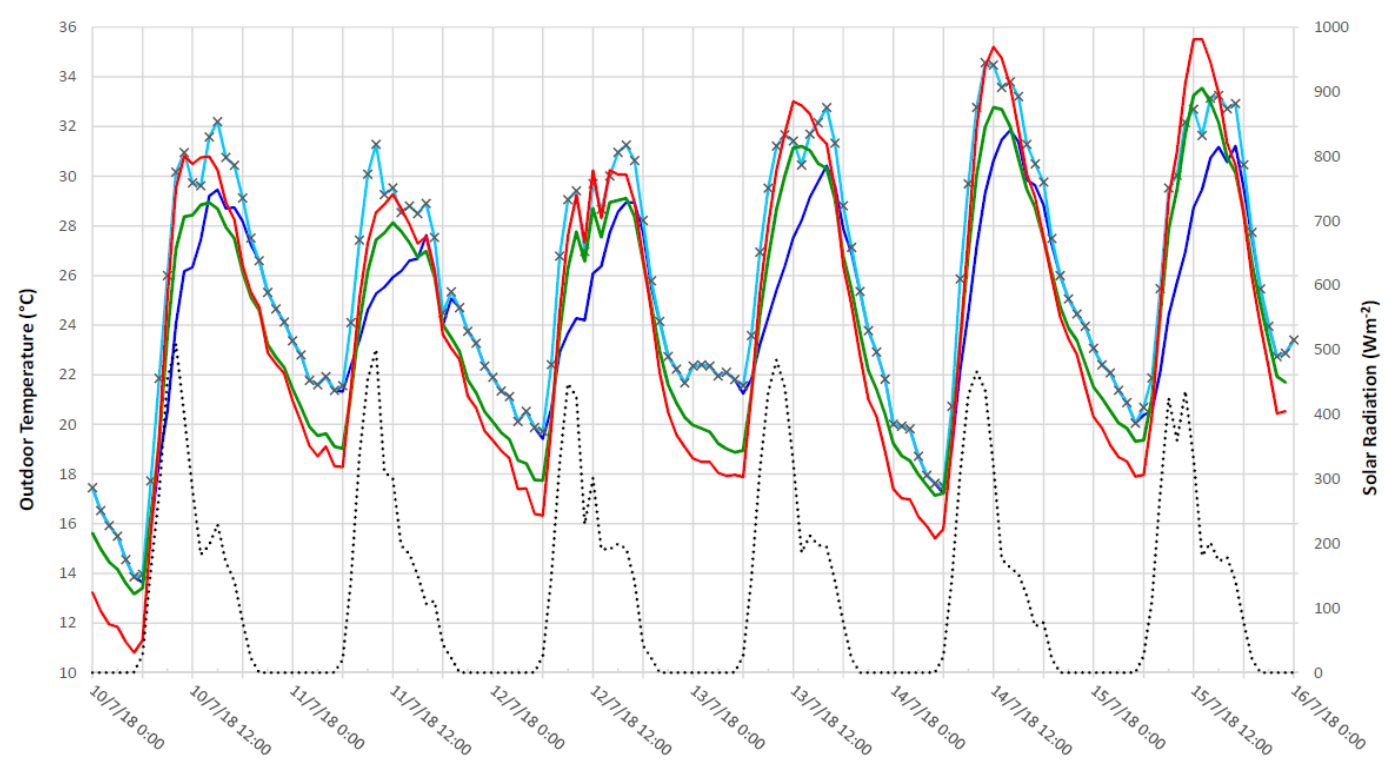

Figure 6. Summer monitoring on 10-15 July: Weather conditions and comparison between external surface temperatures of W1 and W2.

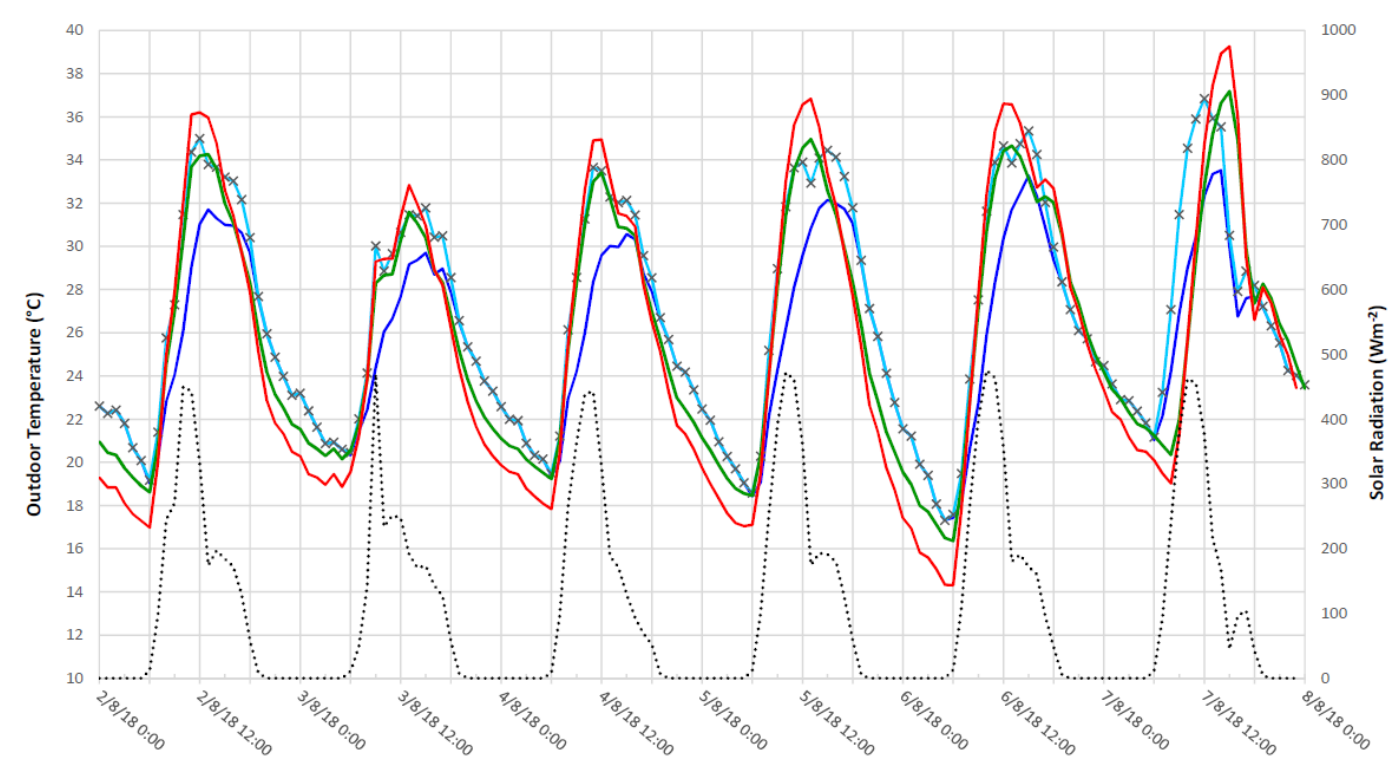

Figure 7. Summer monitoring on 2-7 August: Weather conditions and comparison between external surface temperatures of W1 and W2.

Figures 10 and 11 show the temperatures measured between Wall 0 and W1 or Wall 0 and W2 and those on the internal surface on 2-7 August, which confirm the trend recorded during the previous period for insulated walls W1 and W2. Indeed, the surface temperatures within the insulating layer between $\mathrm{W} 0$ and $\mathrm{W} 1$ ranges between 21.1 and $30.4^{\circ} \mathrm{C}$ while the wall $\mathrm{W} 2$ ranges between 25.1 and $27.3^{\circ} \mathrm{C}$. 


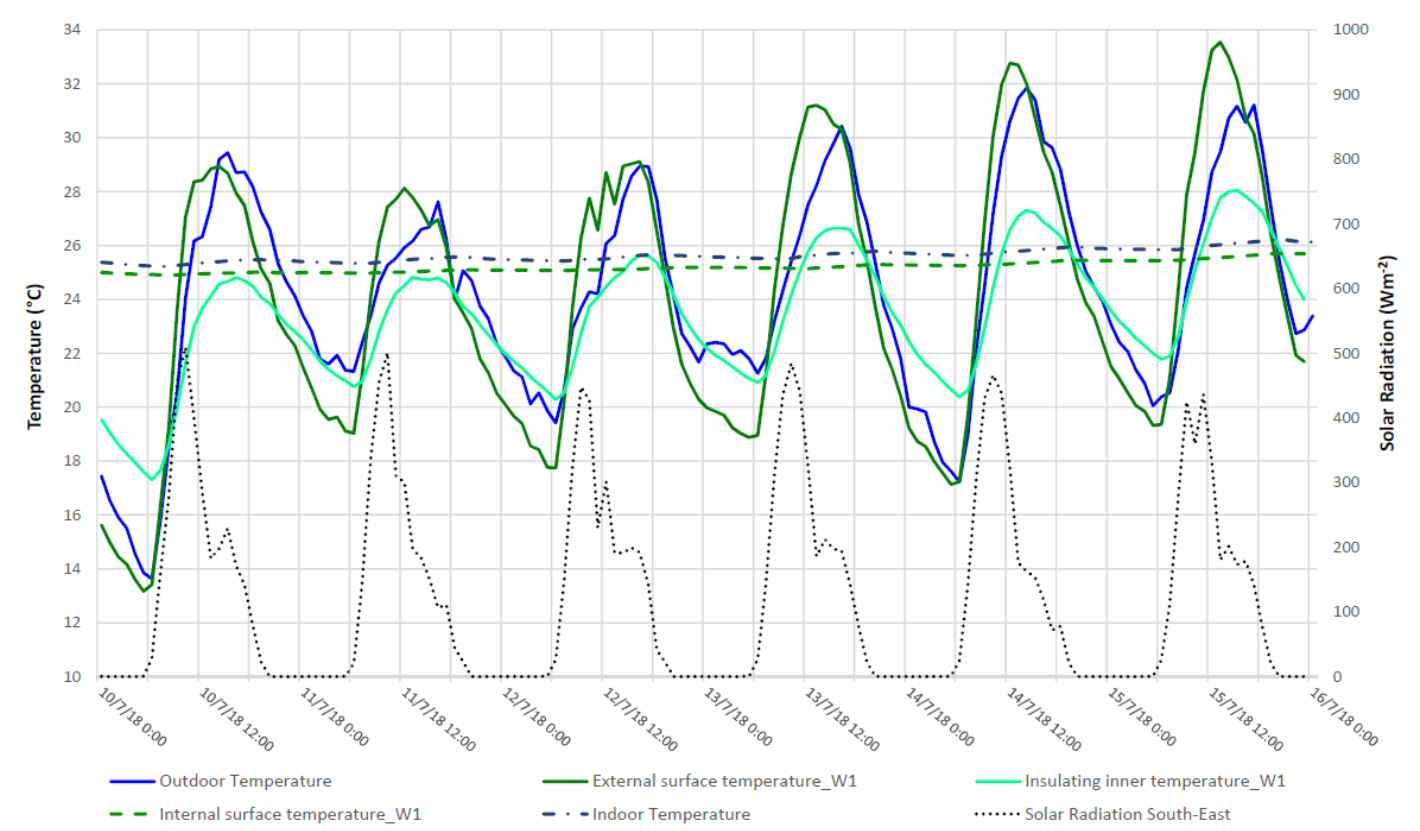

Figure 8. Summer monitoring on 10-15 July: Weather conditions and W1 monitored temperatures.

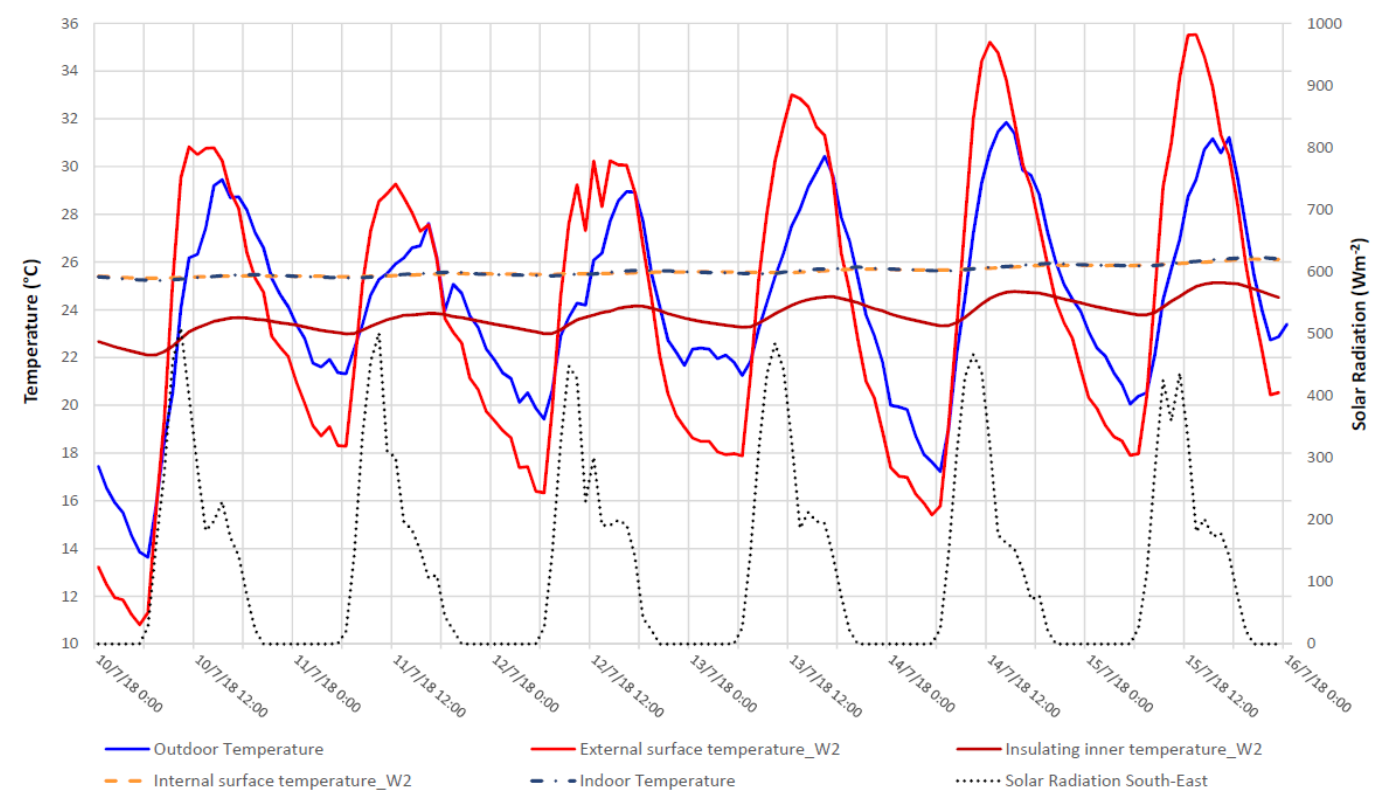

Figure 9. Summer monitoring on 10-15 July: Weather conditions and W2 monitored temperatures.

Instead, the W1 internal surface temperature rises and is equal both for indoor air temperature and W2 internal surface temperature, thus, the three curves overlap.

Figures 12 and 13 show internal surface temperature, indoor air temperature, and the resulting thermal flux. The graphs display that thermal flux through the building envelope, measured on the internal side of the wall, is always outgoing, thus, demonstrating how thermal inertia of the wall allows heat loss during the whole day. 


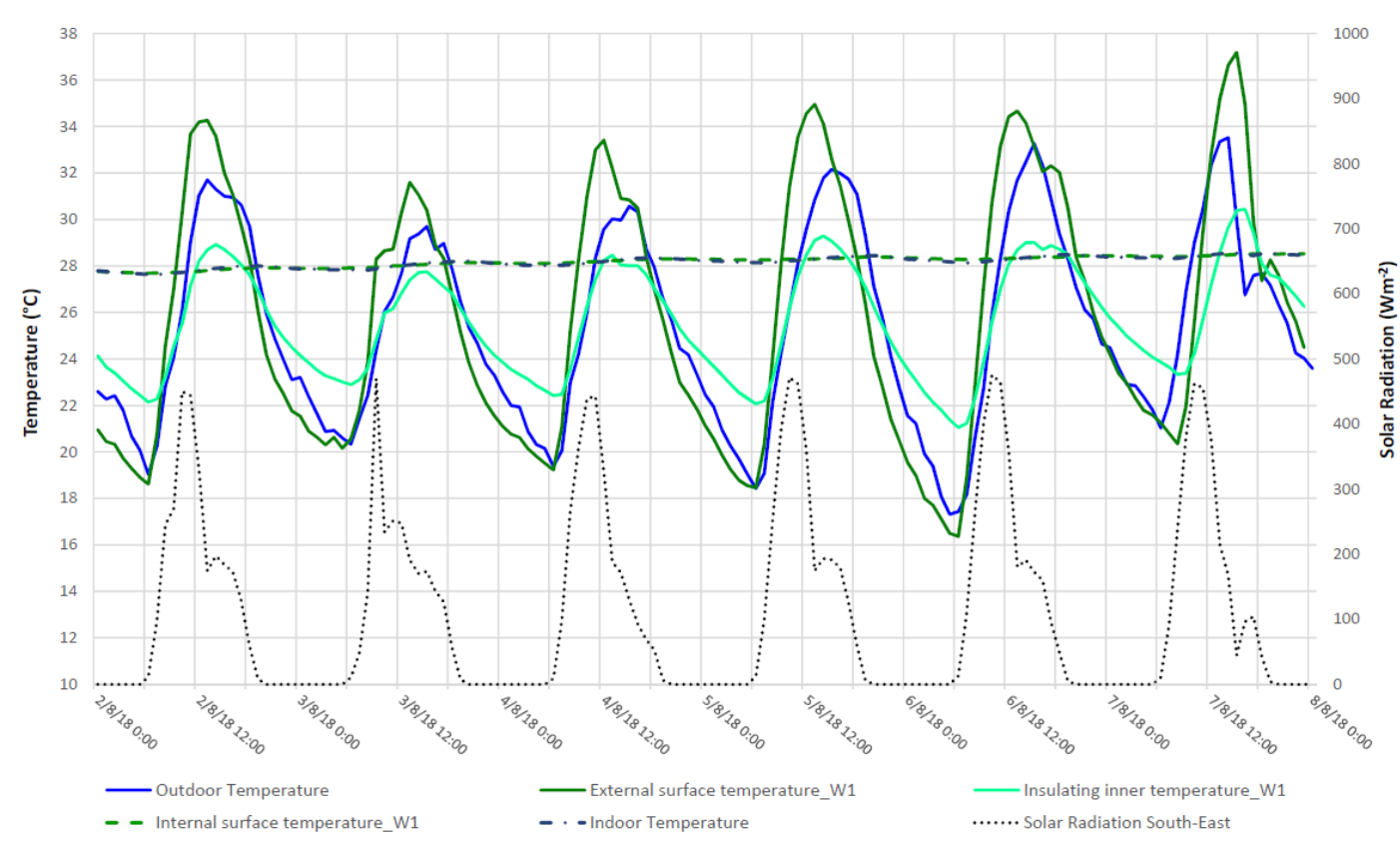

Figure 10. Summer monitoring on 2-7 August: Weather conditions and W1 monitored temperatures.

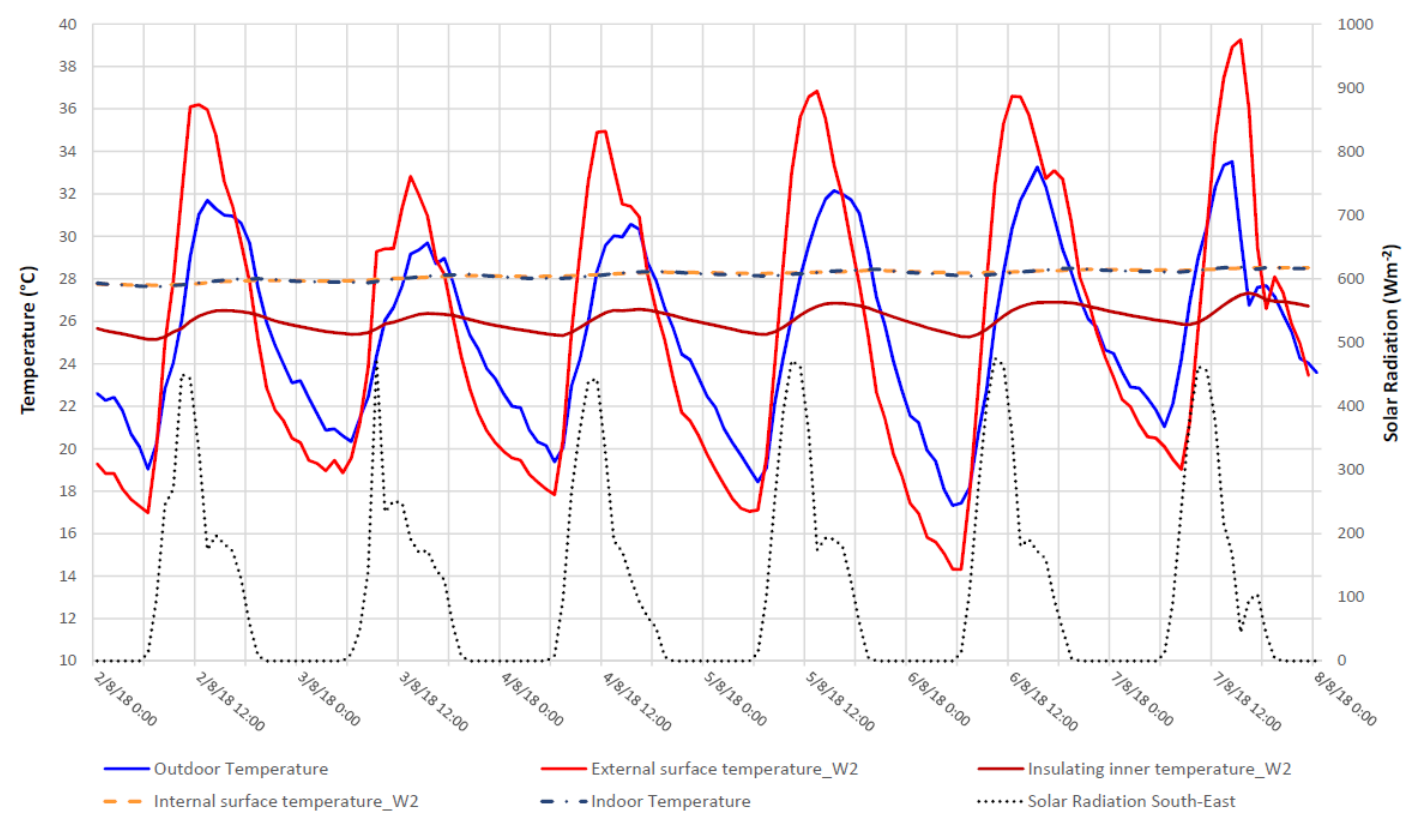

Figure 11. Summer monitoring on 2-7 August: Weather conditions and W2 monitored temperatures.

Tables 5 and 6 present the following statistical parameters: Maximum, minimum, average, and standard deviation.

Average $\left(x_{m}\right)$

\section{Standard deviation $(\sigma)$}

where $z_{i}$ is the $i$-th measured value, $y_{i}$ is the $i$-th measured value of $W 2, x_{i}$ is the $i$-th measured value of $\mathrm{W} 1$, and $\mathrm{N}$ is the total number of period values. Data refer to the two analyzed periods of July and 
August 2018. As expected, the values of standard deviation for the W2 external surface temperature are higher than those of $\mathrm{W} 1$ for both periods.

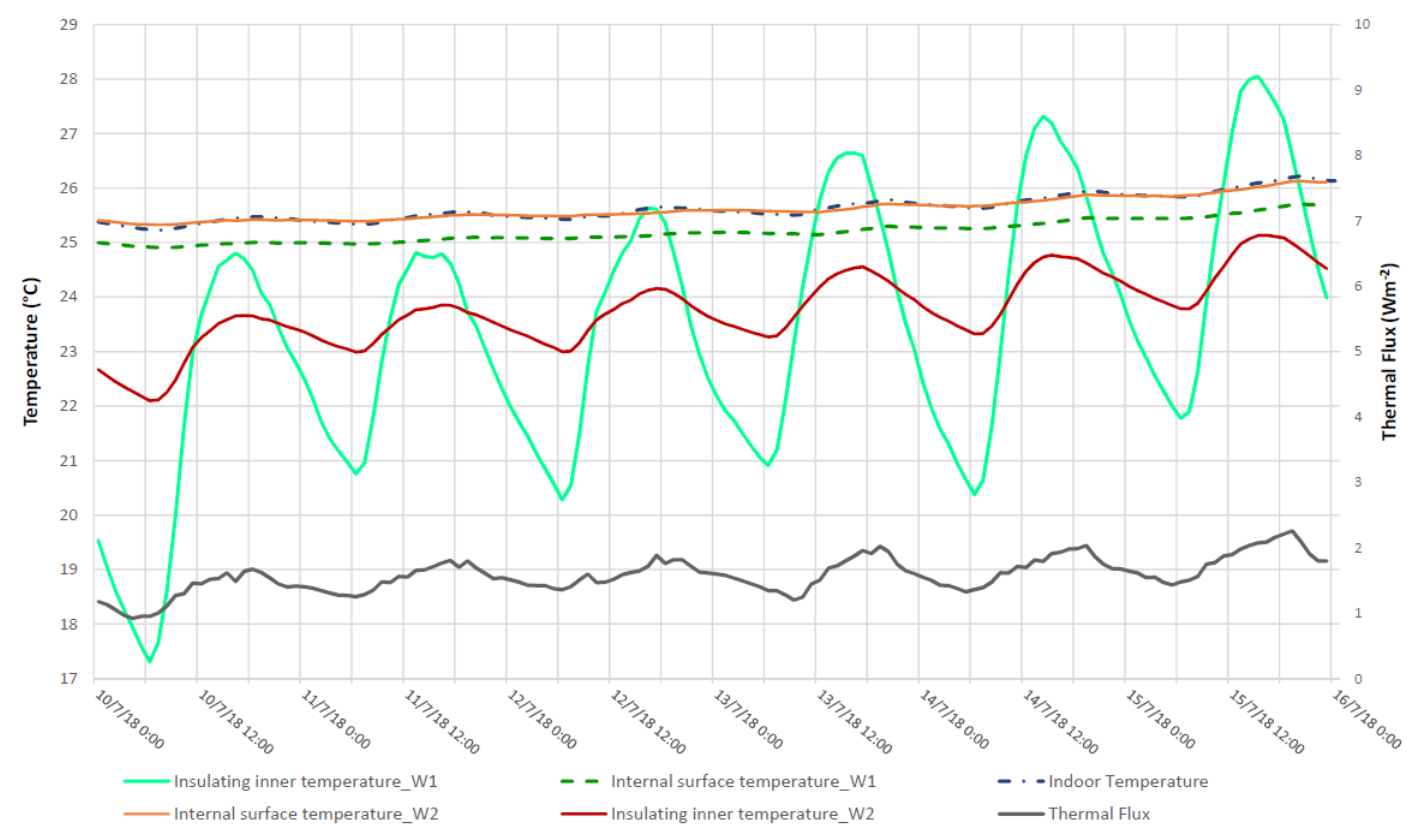

Figure 12. Summer monitoring on 10-15 July: Comparison between W1 and W2 internal surface temperatures and thermal flux.

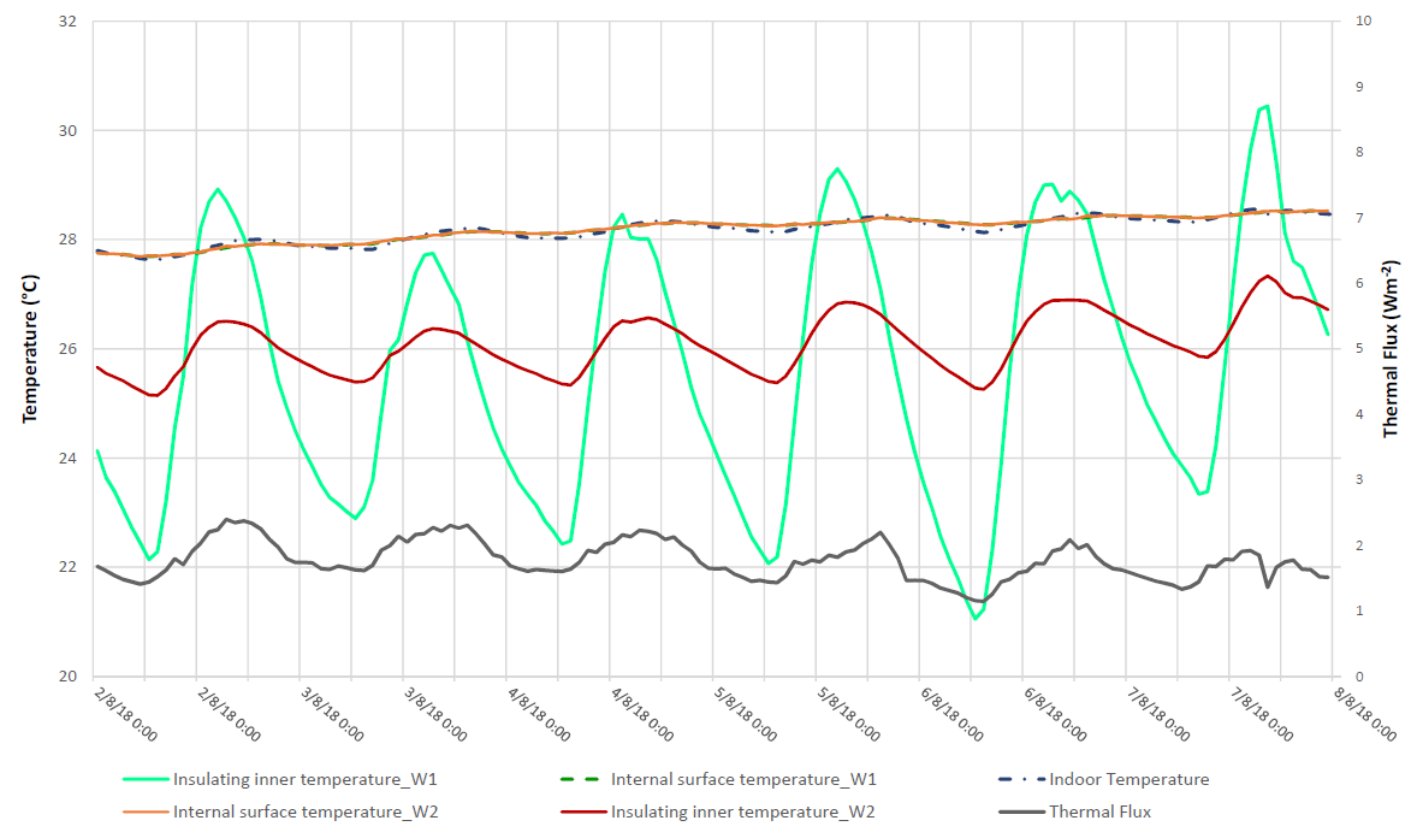

Figure 13. Summer monitoring on 2-7 August: Comparison between W1 and W2 internal surface temperatures and thermal flux. 
Table 5. Statistical data: Summer monitoring on 10-15 July.

\begin{tabular}{|c|c|c|c|c|c|c|c|c|c|}
\hline Date & Range Value & $\begin{array}{c}\text { Outdoor Air } \\
\text { Temperature } \\
\left({ }^{\circ} \mathrm{C}\right)\end{array}$ & $\begin{array}{c}\text { Solar } \\
\text { Irradiance } \\
\text { Southeast } \\
\left(\mathbf{W m}^{-2}\right)\end{array}$ & $\begin{array}{c}\text { External } \\
\text { Surface } \\
\text { Temperature } \\
\text { W1 }\left({ }^{\circ} \mathrm{C}\right)\end{array}$ & $\begin{array}{c}\text { External } \\
\text { Surface } \\
\text { Temperature } \\
\text { W2 }\left({ }^{\circ} \mathrm{C}\right)\end{array}$ & $\begin{array}{c}\text { Surface } \\
\text { Temperature } \\
\text { between } \\
\text { W0-W1 }\left({ }^{\circ} \mathrm{C}\right)\end{array}$ & $\begin{array}{c}\text { Surface } \\
\text { Temperature } \\
\text { between } \\
\text { W0-W2 }\left({ }^{\circ} \mathrm{C}\right)\end{array}$ & $\begin{array}{c}\text { Internal } \\
\text { Surface } \\
\text { Temperature } \\
\text { W1 }\left({ }^{\circ} \mathrm{C}\right)\end{array}$ & $\begin{array}{c}\text { Internal } \\
\text { Surface } \\
\text { Temperature } \\
\text { W2 }\left({ }^{\circ} \mathrm{C}\right)\end{array}$ \\
\hline \multirow{4}{*}{10 July 2018} & Max & 29.5 & 509 & 28.9 & 30.8 & 24.8 & 23.7 & 25.0 & 25.4 \\
\hline & Min & 13.6 & 0 & 13.2 & 10.8 & 17.3 & 22.1 & 24.9 & 25.3 \\
\hline & $x_{m}$ & 22.4 & 130.7 & 22.0 & 21.9 & 21.6 & 23.0 & 25.0 & 25.4 \\
\hline & $\sigma$ & 5.7 & 158.9 & 6.0 & 7.6 & 2.8 & 0.6 & 0.0 & 0.0 \\
\hline \multirow{4}{*}{11 July 2018} & Max & 27.6 & 501 & 28.1 & 29.3 & 24.8 & 23.6 & 25.1 & 25.5 \\
\hline & Min & 21.3 & 0 & 19.0 & 18.3 & 20.8 & 23.0 & 25.0 & 25.4 \\
\hline & $x_{m}$ & 24.1 & 120.2 & 23.5 & 23.5 & 23.0 & 23.5 & 25.0 & 25.4 \\
\hline & $\sigma$ & 1.9 & 155.2 & 3.2 & 3.9 & 1.4 & 0.3 & 0.0 & 0.0 \\
\hline \multirow{4}{*}{ 12July 2018} & Max & 29.0 & 448 & 29.1 & 30.2 & 25.6 & 24.2 & 25.2 & 25.6 \\
\hline & Min & 19.4 & 0 & 17.8 & 16.3 & 20.3 & 23.0 & 25.1 & 25.5 \\
\hline & $x_{m}$ & 23.8 & 120.2 & 23.5 & 23.5 & 23.1 & 23.6 & 25.1 & 25.5 \\
\hline & $\sigma$ & 3.1 & 144.4 & 4.2 & 5.1 & 1.8 & 0.4 & 0.0 & 0.0 \\
\hline \multirow{4}{*}{13 July 2018} & $\operatorname{Max}$ & 30.4 & 484 & 31.2 & 33.0 & 26.7 & 24.6 & 25.3 & 25.7 \\
\hline & Min & 21.3 & 0 & 18.9 & 17.9 & 20.9 & 23.3 & 25.1 & 25.6 \\
\hline & $\mathrm{x}_{\mathrm{m}}$ & 24.9 & 133.4 & 24.6 & 24.5 & 23.8 & 23.9 & 25.2 & 25.6 \\
\hline & $\sigma$ & 3.1 & 161.5 & 4.7 & 5.8 & 2.1 & 0.5 & 0.1 & 0.1 \\
\hline \multirow{4}{*}{14 July 2018} & Max & 31.6 & 466 & 32.8 & 35.2 & 27.3 & 24.8 & 25.5 & 25.9 \\
\hline & Min & 17.2 & 0 & 17.1 & 15.4 & 20.4 & 23.3 & 25.3 & 25.7 \\
\hline & $x_{m}$ & 24.7 & 121.4 & 24.7 & 24.6 & 24.0 & 24.1 & 25.3 & 25.8 \\
\hline & $\sigma$ & 5.0 & 156.9 & 5.5 & 6.9 & 2.5 & 0.5 & 0.1 & 0.1 \\
\hline \multirow{4}{*}{15 July 2018} & $\operatorname{Max}$ & 31.2 & 436 & 33.5 & 35.5 & 28.1 & 25.1 & 25.7 & 26.1 \\
\hline & Min & 20.1 & 0 & 19.3 & 17.9 & 21.8 & 23.8 & 25.4 & 25.9 \\
\hline & $x_{m}$ & 25.2 & 122.6 & 25.7 & 25.6 & 24.9 & 24.5 & 25.5 & 26.0 \\
\hline & $\sigma$ & 3.8 & 147.7 & 5.1 & 6.3 & 2.2 & 0.5 & 0.1 & 0.1 \\
\hline
\end{tabular}


Table 6. Statistical data: Summer monitoring on 2-7 August.

\begin{tabular}{|c|c|c|c|c|c|c|c|c|c|}
\hline Date & Range Value & $\begin{array}{l}\text { Outdoor Air } \\
\text { Temperature } \\
\left({ }^{\circ} \mathrm{C}\right)\end{array}$ & $\begin{array}{c}\text { Solar } \\
\text { Irradiance } \\
\text { Southeast } \\
\left(\mathbf{W m}^{-2}\right)\end{array}$ & $\begin{array}{c}\text { External } \\
\text { Surface } \\
\text { Temperature } \\
\text { W1 }\left({ }^{\circ} \mathrm{C}\right)\end{array}$ & $\begin{array}{c}\text { External } \\
\text { Surface } \\
\text { Temperature } \\
\text { W2 }\left({ }^{\circ} \mathrm{C}\right)\end{array}$ & $\begin{array}{c}\text { Surface } \\
\text { Temperature } \\
\text { between } \\
\text { W0-W1 }\left({ }^{\circ} \mathrm{C}\right)\end{array}$ & $\begin{array}{c}\text { Surface } \\
\text { Temperature } \\
\text { between } \\
\text { W0-W2 }\left({ }^{\circ} \mathrm{C}\right)\end{array}$ & $\begin{array}{c}\text { Internal } \\
\text { Surface } \\
\text { Temperature } \\
\text { W1 }\left({ }^{\circ} \mathrm{C}\right)\end{array}$ & $\begin{array}{c}\text { Internal } \\
\text { Surface } \\
\text { Temperature } \\
\text { W2 }\left({ }^{\circ} \mathrm{C}\right)\end{array}$ \\
\hline \multirow{4}{*}{2 August 2018} & Max & 31.7 & 450 & 34.3 & 36.2 & 28.9 & 26.5 & 27.9 & 27.9 \\
\hline & Min & 19.0 & 0 & 18.6 & 17.0 & 22.1 & 25.1 & 27.7 & 27.7 \\
\hline & $x_{m}$ & 25.5 & 115.5 & 25.6 & 25.3 & 25.4 & 25.9 & 27.8 & 27.8 \\
\hline & $\sigma$ & 4.2 & 145.0 & 5.5 & 6.8 & 2.3 & 0.5 & 0.1 & 0.1 \\
\hline \multirow{4}{*}{3 August 2018} & Max & 29.7 & 470 & 31.6 & 32.8 & 27.8 & 26.4 & 28.18 & 28.15 \\
\hline & Min & 20.3 & 0 & 20.2 & 18.9 & 22.9 & 25.4 & 27.9 & 27.9 \\
\hline & $x_{m}$ & 24.8 & 94.7 & 24.9 & 24.6 & 25.2 & 25.9 & 28.0 & 28.0 \\
\hline & $\sigma$ & 3.2 & 122.1 & 4.0 & 4.9 & 1.7 & 0.3 & 0.1 & 0.1 \\
\hline \multirow{4}{*}{4 August 2018} & Max & 30.6 & 443 & 33.4 & 35.0 & 28.5 & 26.6 & 28.3 & 28.3 \\
\hline & Min & 19.4 & 0 & 19.2 & 17.8 & 22.4 & 25.3 & 28.1 & 28.1 \\
\hline & $x_{m}$ & 25.0 & 110.6 & 25.4 & 25.1 & 25.4 & 26.0 & 28.2 & 28.2 \\
\hline & $\sigma$ & 3.7 & 149.2 & 4.9 & 5.9 & 2.1 & 0.4 & 0.1 & 0.1 \\
\hline \multirow{4}{*}{5 August 2018} & Max & 32.2 & 472 & 34.9 & 36.8 & 29.3 & 26.9 & 28.4 & 28.4 \\
\hline & Min & 18.4 & 0 & 18.5 & 17.0 & 22.1 & 25.4 & 28.3 & 28.3 \\
\hline & $x_{m}$ & 25.5 & 124.1 & 25.6 & 25.3 & 25.5 & 26.1 & 28.3 & 28.3 \\
\hline & $\sigma$ & 4.8 & 158.6 & 5.9 & 7.2 & 2.5 & 0.5 & 0.0 & 0.0 \\
\hline \multirow{4}{*}{6 August 2018} & Max & 33.3 & 475 & 34.7 & 36.6 & 29.0 & 26.9 & 28.4 & 28.5 \\
\hline & Min & 17.3 & 0 & 16.4 & 14.3 & 21.1 & 25.3 & 28.3 & 28.3 \\
\hline & $x_{m}$ & 25.1 & 122.5 & 26.1 & 25.9 & 25.6 & 26.2 & 28.3 & 28.3 \\
\hline & $\sigma$ & 5.3 & 159.9 & 6.7 & 8.1 & 3.0 & 0.6 & 0.1 & 0.1 \\
\hline \multirow{4}{*}{7 August 2018} & Max & 33.5 & 462 & 37.2 & 39.3 & 30.4 & 27.3 & 28.5 & 28.5 \\
\hline & Min & 21.0 & 0 & 20.4 & 19.0 & 23.3 & 25.8 & 28.4 & 28.4 \\
\hline & $\mathrm{x}_{\mathrm{m}}$ & 26.3 & 112.1 & 26.7 & 26.6 & 26.3 & 26.5 & 28.5 & 28.5 \\
\hline & $\sigma$ & 3.7 & 157.4 & 5.3 & 6.4 & 2.3 & 0.5 & 0.0 & 0.0 \\
\hline
\end{tabular}




\subsection{Analytical Results: Summer Monitoring 2018}

In order to test the correspondence between the monitored and analytical results, the TRNSYS analysis focuses on the same two periods of six consecutive days.

Figure 14a,b shows the comparison for W1 between recorded values of external surface temperatures and the simulated ones: Results highlight how TRNSYS does not accurately reproduce the experimental measures. Indeed, the calculated external surface temperatures are underestimated compared to the real values achieved on the warmest summer periods.

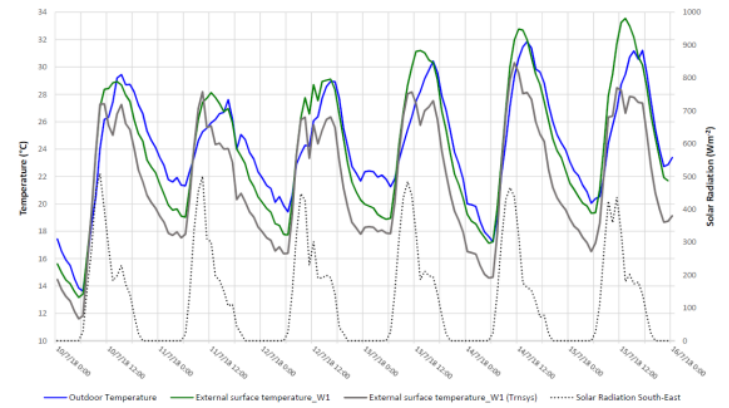

(a)

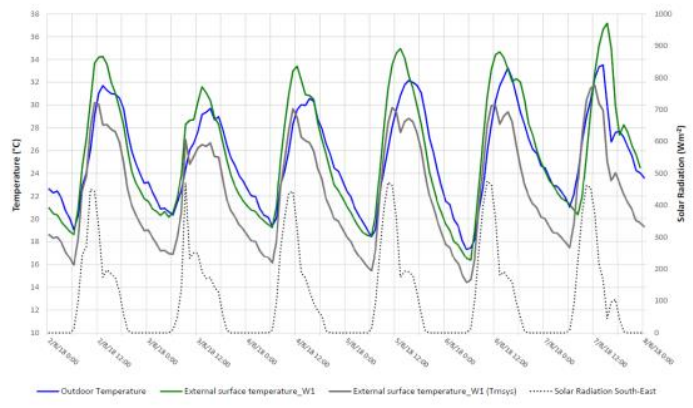

(b)

Figure 14. (a) Comparison between measured and simulated values of W1 in July, (b) comparison between measured and simulated values of W1 in August.

Similar considerations can be made for the W2: Specifically, the simulated values of an external surface temperature show a large underestimation compared to the measured ones (Figure 15a,b).

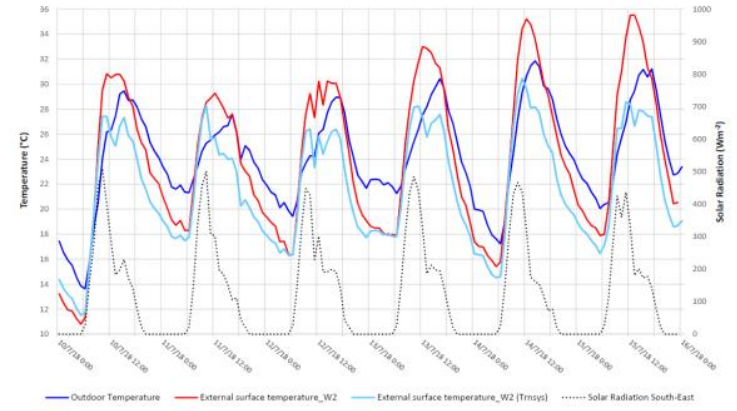

(a)

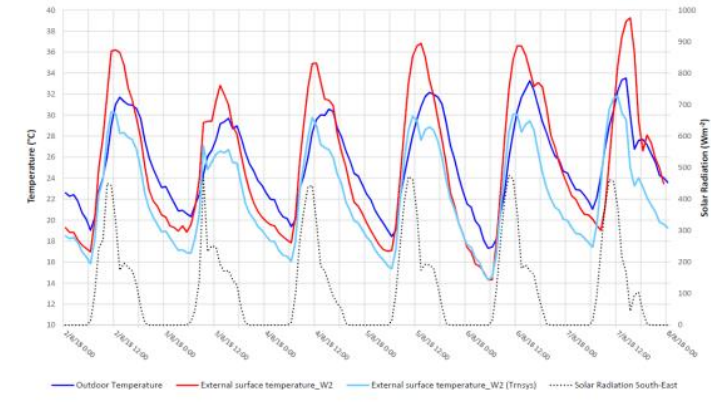

(b)

Figure 15. (a) Comparison between measured and simulated values of W2 in July, (b) comparison between measured and simulated values of W2 in August.

Figures 16 and 17 show the trend of the internal surface temperatures compared to the monitored indoor air temperature. Discrepancy between measured and simulated values is also observed in the internal surface temperatures, where the error is less evident in terms of numerical value but more evident in terms of general trend. Analytical internal surface temperatures are underestimated and have a large fluctuation for both W1 and W2 compared to the measured trends, which, on the contrary, are more linear. 


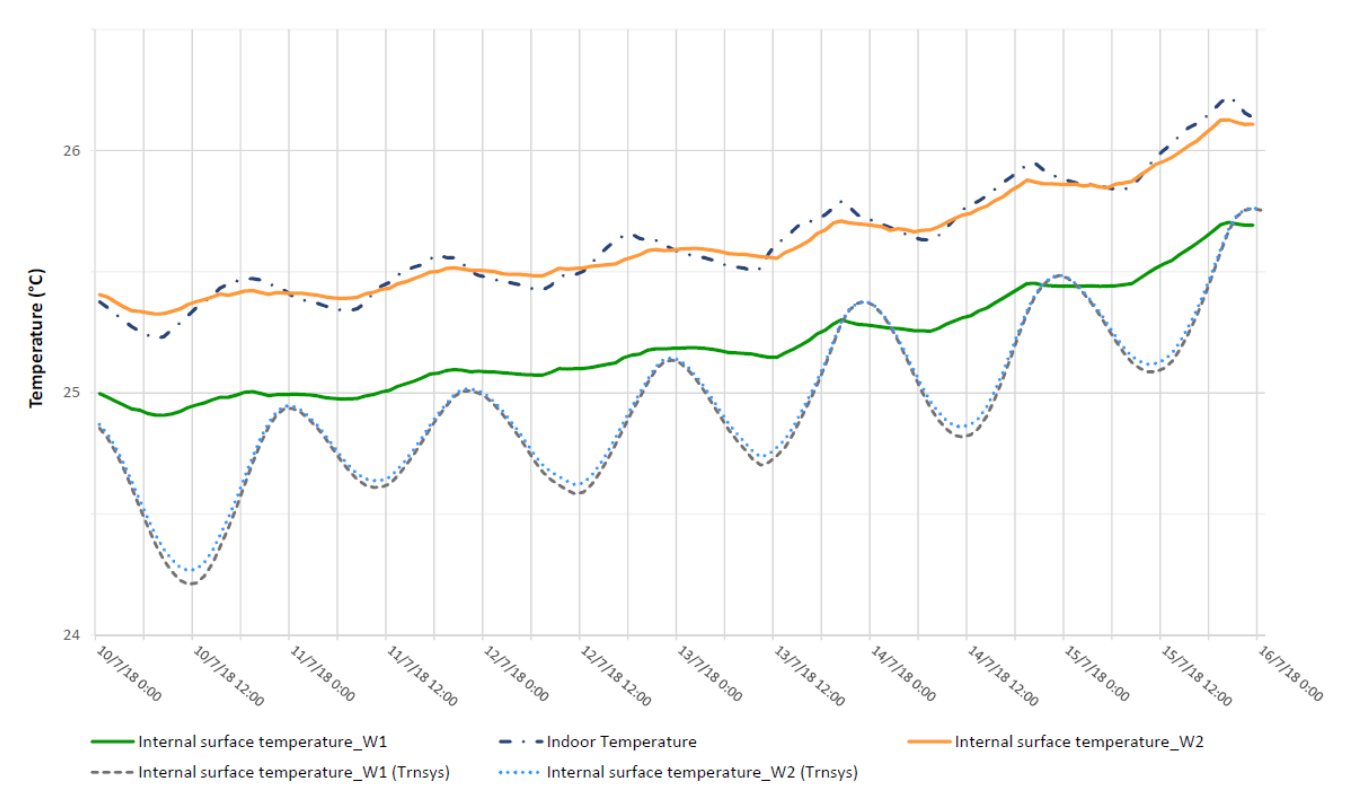

Figure 16. Comparison between recorded and simulated values of W1 and W2 on 10 -15 July.

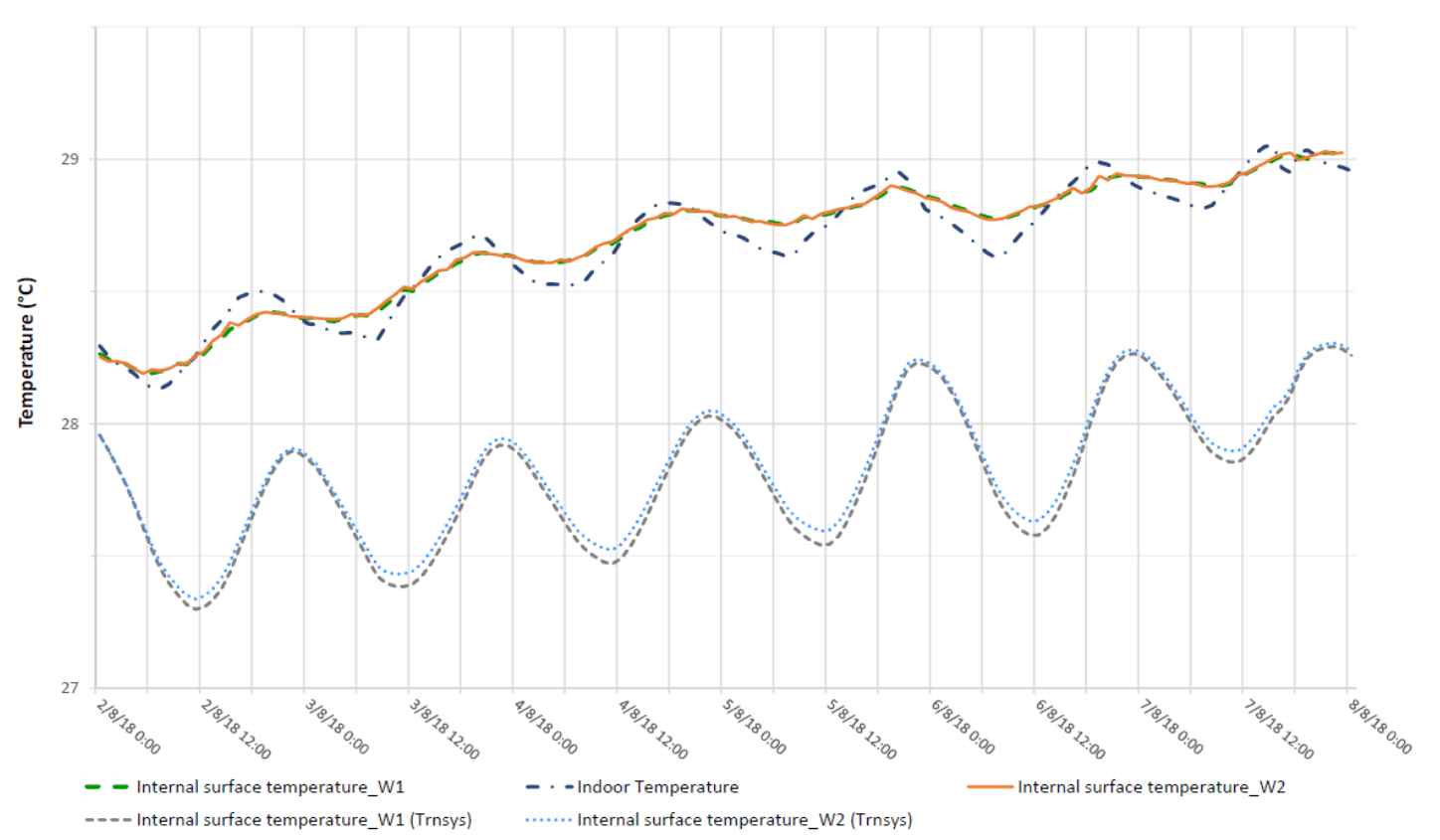

Figure 17. Comparison between recorded and simulated values of W1 and W2 on 2-7 August.

\section{Discussion}

The present experimental study aims to investigate the thermal behavior of a high thermal inertia building, characterized by two different external insulating materials, under Mediterranean climatic conditions. The monitored mockup is made of a lightweight concrete (LWC) with lightweight recycled glass aggregates; its walls, floor, and roof have a thickness of $70 \mathrm{~cm}$ to guarantee high thermal inertia. Thus, the initial building (W0) is a massive structure with high thermal capacity $\left(840 \mathrm{~kJ} \mathrm{~m}^{-2} \mathrm{~K}^{-1}\right)$. In order to reach the National standard for thermal transmittance (U), two different external insulating layers are added on the Southeast façade, i.e., thermal plaster and XPS, named W1 and W2, respectively, which have similar thermal conductivity, but different specific weight $\rho$ and water vapor permeability $\mu$.

Data recorded during the two monitoring campaigns in 2018 and 2019 confirm the repeatability of the different observed behaviors of the two insulating systems. 
Collected data demonstrate a relationship between monitored external surface temperatures on insulated walls W1 and W2 and weather conditions, namely air temperature and solar irradiance.

Results show that W2 undergoes higher thermal stress than W1, due to higher peaks in external surface temperature and large fluctuations in daily temperature. This behavior is highlighted through statistical data, such as standard deviation calculated for the external surface temperature, as reported in Tables 5 and 6. The W2 values are 19.1\% and 18.0\% higher than W1 in July and June 2018, respectively. Analyzed results show that the XPS insulated system (W2) heats up more and faster than the thermal plaster insulation (W1) but releases the stored heat more quickly. A deep analysis of the properties of the two external insulating systems could explain this behavior. First, the thermal resistance of W2 $(2.22 \mathrm{Kmq} / \mathrm{W})$ is twice that of $\mathrm{W} 1(1.08 \mathrm{Kmq} / \mathrm{W})$, due to similar thermal conductivity but W2 is twice as thick as W1. Therefore, a more performing external insulation limits the transmission of the thermal flux toward inner layers of the wall, thus, the superficial external surface shows an increase in temperature.

Secondly, the external areal heat capacities of the two walls could be considered: 15.6 and $9.3 \mathrm{~kJ} / \mathrm{m}^{2} \mathrm{~K}$ for $\mathrm{W} 1$ and $\mathrm{W} 2$, respectively. This parameter assumes high relevance for a proper building envelope design in accordance with the research of Stazi et al. [23], in which the internal areal heat capacity is analyzed to prevent indoor air overheating.

Moreover, it is significant to observe that both internal surface temperatures result almost linear and do not undergo considerable fluctuations, due to the high heat capacity of the massive building.

Therefore, indoor air temperature does not significantly change and even equal internal surface temperatures of W1 and W2 in the warmest period of August.

Contrary to the external surface, monitored surface temperatures between the insulating layer and LWC show a different behavior; indeed, W1 displays larger fluctuations. The reason should be found in thermal conductivity and thickness of the different insulating layer, as previously stated.

In order to guarantee indoor thermal comfort, proper design of the building envelope is of utmost relevance in Mediterranean climates characterized by warm summer. This experimental study highlights the importance of thermal inertia in building envelope, focusing on parameters such as external areal heat capacity $\left(\mathrm{k}_{2}\right)$ and thermal resistance $(\mathrm{R})$.

Specifically, a high value of thermal resistance of the external insulation and low value of external areal heat capacity $\left(\mathrm{k}_{2}\right)$ on a massive building causes external surface overheating problems, thus, not representing the best construction solution. Indeed, the highest thermal stress can cause negative effects in terms of durability, such as the formation of microcracks on the external surface, which can lead to further problems on the wall because of infiltration of rain water. In addition to threatening the integrity of the façade (i.e., adhesion and cohesion), water infiltration alters the thermal performances of the insulating material, thus, not guaranteeing the initial insulation [28]. Indeed, a moderate increase in water absorption causes a high decrease in thermal conductivity.

A part of this research concerns simulations of the physical phenomenon using a virtual model implemented in TRNSYS. Results show a large discrepancy between analytical and simulated values; indeed, a wide underestimation is observed in terms of amplitude and a small difference is noted in terms of phase shift.

Based on these results, further analysis could be performed to quantify the influence of areal heat capacity and thermal resistance on the surface temperature trends of building envelope provided with high thermal inertia and insulation.

Author Contributions: Data curation, C.T.; Investigation, C.T.; Project administration, C.D.P.; Software, L.T. and S.S.; Supervision, C.D.P.; Visualization, C.T.; Writing-original draft, C.T. and L.T.; Writing-review \& editing, C.T., L.T., S.S.and C.D.P. All authors have read and agreed to the published version of the manuscript.

Funding: This research received no external funding.

Conflicts of Interest: The authors declare no conflict of interest. 


\section{References}

1. U.S. Energy Information Administration (EIA). International Energy Outlook 2019 with Projections to 2050. September 2019. Available online: https://www.eia.gov/ieo (accessed on 1 July 2020).

2. Directive (EU) 2018/844 of the European Parliament and of the Council of 30 May 2018 on the Energy Performance of Buildings. Available online: http://data.europa.eu/eli/dir/2018/844/oj (accessed on 19 June 2018).

3. Yoshinoa, H.; Hong, T.; Nord, N. EA EBC annex 53: Total energy use in buildings-Analysis and evaluation methods. Energy Build. 2017, 152, 124-136. [CrossRef]

4. Antonaia, A.; Ascione, F.; Castaldo, A.; Angelo, A.D.; De Masi, R.F.; Ferrara, M.; Vanoli, G.P.; Vitiello, G. Cool materials for reducing summer energy consumptions in Mediterranean climate: In-lab experiments and numerical analysis of a new coating based on acrylic paint. Appl. Therm. Eng. 2016, 102, 91-107. [CrossRef]

5. Congedo, P.M.; Baglivo, C.; Centonze, G. Walls comparative evaluation for the thermal performance improvement of low-rise residential buildings in warm Mediterranean climate. J. Build. Eng. 2020, 28, 101059. [CrossRef]

6. Gamero-Salinas, J.C.; Monge-Barrio, A.; Sanchez-Ostiz, A. Overheating risk assessment of different dwellings during the hottest season of a warm tropical climate. Build. Environ. 2020,171, 106664. [CrossRef]

7. Hashemi, A.; Khatami, N. Effects of solar shading on thermal comfort in low-income tropical housing. Energy Procedia 2017, 111, 235-244. [CrossRef]

8. Pathirana, S.; Rodrigo, A.; Halwatura, R. Effect of building shape, orientation, window to wall ratios and zones on energy efficiency and thermal comfort of naturally ventilated houses in tropical climate. Int. J. Energy Environ. Eng. 2019, 10, 107-120. [CrossRef]

9. Santamouris, M.; Kolokotsa, D. Passive cooling dissipation techniques for buildings and other structures: The state of the art. Energy Build. 2013, 57, 74-94. [CrossRef]

10. Van Hooff, T.; Blocken, B.; Timmermans, H.J.P.; Hensen, J.L.M. Analysis of the predicted effect of passive climate adaptation measures on energy demand for cooling and heating in a residential building. Energy 2016, 94, 811-820. [CrossRef]

11. Kuczynski, T.; Staszczuk, A. Experimental study of the influence of thermal mass on thermal comfort and cooling energy demand in residential buildings. Energy 2020, 195, 116984. [CrossRef]

12. Harkouss, F.; Fardoun, F.; Biwole, P.H. Passive design optimization of low energy buildings in different climates. Energy 2018, 165, 591-613. [CrossRef]

13. Baglivo, C.; Congedo, P.M.; Fazio, A.; Laforgia, D. Multiobjective optimization analysis for high efficiency external walls of zero energy buildings (ZEB) in the Mediterranean climate. Energy Build. 2014, 84, 483-492. [CrossRef]

14. Baglivo, C.; Congedo, P.M. High performance precast external walls for cold climate by a multi-criteria methodology. Energy 2016, 115, 561-576. [CrossRef]

15. Cardinale, N.; Rospi, G.; Stefanizzi, P. Energy and microclimatic performance of Mediterranean vernacular buildings: The Sassi district of Matera and the Trulli district of Alberobello. Build. Environ. 2013, 59, 590-598. [CrossRef]

16. Xu, C.C.; Li, S.L.; Zou, K.K. Study of heat and moisture transfer in internal and external wall insulation configurations. J. Build. Eng. 2019, 24, 2352-7102. [CrossRef]

17. Cheng, F.; Zhang, X.; Su, X. Comparative assessment of external and internal insulation for intermittent air-conditioned bedrooms in Shanghai. Procedia Eng. 2017, 205, 50-55. [CrossRef]

18. Verbekea, S.; Audenaerta, A. Thermal inertia in buildings: A review of impacts across climate and building use. Renew. Sustain. Energy Rev. 2018, 82, 2300-2318. [CrossRef]

19. Stazi, F.; Vegliò, A.; Di Perna, C.; Munafò, P. Experimental comparison between 3 different traditional wall construction and dynamic simulations to identify optimal thermal insulation strategies. Energy Build. 2013, 60, 429-441. [CrossRef]

20. Rossi, M.; Rocco, V.M. External walls design: The role of periodic thermal transmittance and internalareal heat capacity. Energy Build. 2014, 68, 732-740. [CrossRef]

21. Aste, N.; Angelotti, A.; Buzzetti, M. The influence of external walls thermal inertia on the energy performance of well insulated buildings. Energy Build. 2009, 41, 1181-1187. [CrossRef] 
22. Di Perna, C.; Stazi, F.; Ursini Casalena, A.; Orazio, M.D. Influence of the internal inertia of the building envelope on summertime comfort in buildings with high internal heat loads. Energy Build. 2011, 43, $200-206$. [CrossRef]

23. Stazi, F.; Ulpiani, G.; Pergolini, M.; Di Perna, C. The role of areal heat capacity and decrement factor in case of hyper insulated buildings: An experimental study. Energy Build. 2018, 176, 310-324. [CrossRef]

24. DECRETO 26 Giugno 2015. Applicazione Delle Metodologie di Calcolo Delle Prestazioni Energetiche e Definizione Delle Prescrizioni e dei Requisiti Minimi Degli Edifici, GU Serie Generale n.162 del 15-07-2015-Suppl. Ordinario n. 39. Available online: https://www.gazzettaufficiale.it/eli/id/2015/07/ 15/15A05198/sg (accessed on 15 July 2015).

25. Reindl, D.T.; Beckman, W.A.; Duffie, J.A. Diffuse fraction correlations. Sol. Energy 1990, 45, 1-7. [CrossRef]

26. Perez, R.; Ineichen, P.; Seals, R.; Michalsky, J.; Stewart, R. Modeling daylight availability and irradiance components from direct and global irradiance. Sol. Energy 1990, 44, 271-289. [CrossRef]

27. Kontoleon, K.J.; Theodosiou, T.G.; Tsikaloudaki, K.G. The influence of concrete density and conductivity on walls' thermal inertia parameters under a variety of masonry and insulation placements. Appl. Energy 2013, 112, 325-337. [CrossRef]

28. Guerra, E.P. Risanamento di Murature Umide e Degradate Sintomi e Cause-Rimedi-Soluzioni Progettuali, 3rd ed.; Dario Flaccovio Editore: Palermo, Italy, 2014.

(C) 2020 by the authors. Licensee MDPI, Basel, Switzerland. This article is an open access article distributed under the terms and conditions of the Creative Commons Attribution (CC BY) license (http://creativecommons.org/licenses/by/4.0/). 